\title{
Milestones for Disposal of Radioactive Waste at the Waste Isolation Pilot Plant (WIPP) in the United States
}

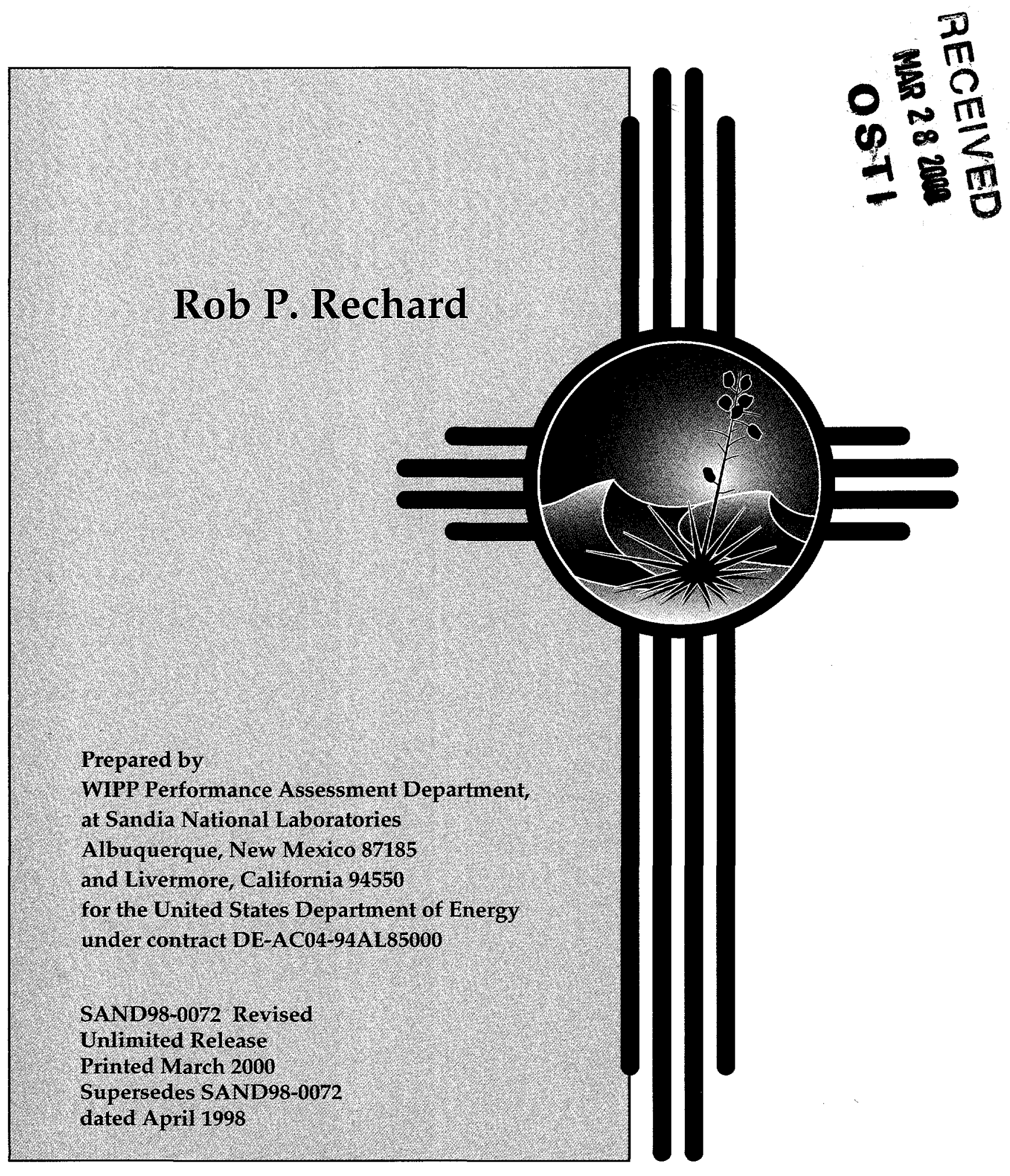


Issued by Sandia National Laboratories, operated for the United States Department of Energy by Sandia Corporation.

NOTICE: This report was prepared as an account of work sponsored by an agency of the United States Government. Neither the United States Government, nor any agency thereof, nor any of their employees, nor any of their contractors, subcontractors, or their employees, make any warranty, express or implied, or assume any legal liability or responsibility for the accuracy, completeness, or usefulness of any information, apparatus, product, or process disclosed, or represent that its use would not infringe privately owned rights. Reference herein to any specific commercial product, process, or service by trade name, trademark, manufacturer, or otherwise, does not necessarily constitute or imply its endorsement, recommendation, or favoring by the United States Government, any agency thereof, or any of their contractors or subcontractors. The views and opinions expressed herein do not necessarily state or reflect those of the United States Government, any agency thereof, or any of their contractors.

Printed in the United States of America. This report has been reproduced directly from the best available copy.

Available to DOE and DOE contractors from Office of Scientific and Technical Information

P.O. Box 62

Oak Ridge, TN 37831

Prices available from (703) 605-6000

Web site: http://www.ntis.gov/ordering.htm

Available to the public from

National Technical Information Service

U.S. Department of Commerce

5285 Port Royal Rd

Springfield, VA 22161

NTIS price codes

Printed copy: A03

Microfiche copy: A01

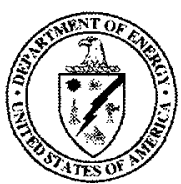




\section{DISCLAIMER}

Portions of this document may be illegible in electronic image products. Images are produced from the best available original document. 


\title{
Milestones for Disposal of Radioactive Waste at the Waste Isolation Pilot Plant (WIPP) in the United States
}

\author{
Rob P. Rechard \\ Performance Assessment Department (6849) \\ Sandia National Laboratories \\ Albuquerque, NM 87185-0779
}

\begin{abstract}
Six years (1983 to 1989) were spent constructing the Waste Isolation Pilot Plant (WIPP) in southern New Mexico for disposal of transuranic radioactive waste. However, not until 1999, 25 years after its identification as a potential deep geologic repository, did the WIPP receive its first shipment of waste. This report presents a concise history in tabular form of events leading up to its selection, including the development of regulatory criteria, major political conflicts, negotiated agreements, and technical milestones of the WIPP. In general, technical programs and engineering analysis of the WIPP before the mid 1980s were undertaken primarily (1) to develop general understanding of selected natural phenomena, (2) to satisfy needs for environmental impact statements, and (3) to satisfy negotiated agreements between the U.S. Department of Energy and the State of New Mexico. In the final segment of the project, federal compliance policy was developed and technical programs and engineering analysis evolved to assess the compliance of the WIPP with these specific regulations. During this ten-year period, four preliminary performance assessments, one compliance performance assessment, and one verification performance assessment were performed.
\end{abstract}




\section{Preface}

The milestones table for the Waste Isolation Pilot Plant (WIPP) Project was originally prepared as a section in the report, An Introduction to the Mechanics of Performance Assessment Using Examples of Calculations Done for the Waste Isolation Pilot Plant Between 1990 and 1992, SAND93-1378, by Rob P. Rechard. The milestones table, a particularly popular section, has been reproduced separately here and has been updated to include 1996 through 1999. As before, some text accompanies the milestone tables, but the emphasis remains on the tables because of their usefulness in providing a comprehensive but concise history of the WIPP. The usefulness of the milestones table is due in part to Anita Reiser, Darrell Munson, and Wendell Weart, all of Sandia National Laboratories, who helped with verification of information; C. Crawford of ASAP, Inc., who verified references; M. Minahan and J. Chapman, of Tech Reps, Inc., who edited the text; and S. K. Best, of Tech Reps, Inc., who placed the text in tables. 


\section{Contents}

Acronyms/Initialisms

Milestones for Disposal of Radioactive Waste at the Waste Isolation Pilot Plant .1

Early History of Nuclear Waste Disposal Related to the WIPP .1

Early Studies at the WIPP

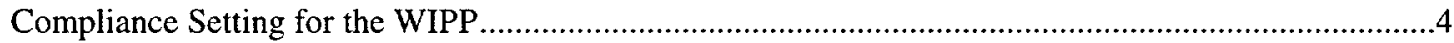

Development of Methodology for Assessing Compliance of the WIPP ...............................................

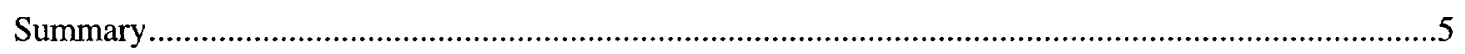

Detailed Tabulation of WIPP Milestones ...........................................................................................

References

.20 


\section{Acronyms/Initialisms}

$\mathbf{A} / \mathbf{E}$ - architect/engineering firm

AEA - Atomic Energy Act, either 1946 (Pub. L. 79585-60 Stat. 755) or 1954 (Pub. L. 83-703-68 Stat. 919)

AEC - Atomic Energy Commission, the forerunner of the DOE, was formed in 1946 (August 1, 1946, 60 Stat. 755).

AG - Attorney General

AL - Albuquerque Operations Office, largest of several operations offices set up by DOE

ALARA - As low as reasonably achievable with costs and benefits taken into account; a basic policy of radiation protection initially proposed in 1948 and promulgated by NRC in 1975.

BRWM - Board of Radioactive Waste Management, a permanent board formed in 1968 in the National Research Council, the operating agency of the U.S. National Academy of Sciences (NAS)

BSPP - Bedded Salt Pilot Plant, initial name for WIPP in 1974

C\&C - Consultation and Cooperation Agreement Between the State of New Mexico and the DOE

CAG - Compliance Application Guide, a non-binding guidance document developed by the EPA to supplement the WIPP implementing regulation, Title 40 CFR Part 191

CAMCON - Compliance Assessment Methodology CONtroller, computational system for assessing the performance of a disposal system (usually for nuclear wastes). When first developed in the early $1990 \mathrm{~s}$, this information management system provided for (1) the interfacing of individual computer codes of the WIPP PA modeling system, and (2) quality assurance of the computations.

CAO - Carlsbad Area Office, DOE office for managing WIPP Project, was formed in 1993 to replace the WIPP Project Integration Office (WPIO) that had been established in 1991, and the WIPP Project Office (WPO), which had been created in the 1980s and moved to Carlsbad, NM, in 1984.

CARD - Citizens Against Radioactive Dumping, New Mexico special interest group

CCA - Compliance Certification Application to the EPA to evaluate compliance with Title 40 CFR Part 191 of the Waste Isolation Pilot Plant; application coordinated by Westinghouse for the DOE with input from Sandia National Laboratories
CH-TRU - contact-handled Transuranic waste, packaged TRU waste whose external surface dose rate does not exceed 200 mrem per hour and can thus be directly handled by personnel

CFR - Code of Federal Regulations

DCCA - Draft Compliance Certification Application, prepared and sent to EPA in 1995

DHLW - Defense high-level waste, that is, high-level waste (HLW) that has been generated by the DOE in reprocessing spent nuclear fuel from experimental and military reactors. Because the possibility of commercial reprocessing was stopped under the Carter Administration in 1980 and never initiated thereafter, only about 72 MTHM equivalents from the West Valley Demonstration Project in New York or $0.75 \%$ is commercial HLW in the United States. Hence, the distinction between defense and commercial HLW is usually unimportant, except when highlighting the source of HLW or when discussing reprocessing and disposal plans for HLW in the United States prior to 1980 .

DOE - U.S. Department of Energy, formed by DOE Organization Act (Pub. L. 95-91, 91 Stat. 565), which replaced the Energy Research and Development Agency (ERDA). ERDA was formed by the 1974 Energy Reorganization Act (Pub. L. 93-438) and replaced the Atomic Energy Commission (AEC), which was formed in 1946 (August 1, 1946, 60 Stat. 755).

DOI - U.S. Department of Interior

DOL - U.S. Department of Labor

DOT - U.S. Department of Transportation

EDF - Environmental Defense Fund, U.S. environmental special interest group

EEG - Environmental Evaluation Group, formed in 1978 by New Mexico from funds provided by the DOE to conduct independent technical evaluation of the WIPP. The National Defense Authorization Act, Fiscal Year 1989, Pub. L. 100-456, Section 1433 assigned administrative oversight of EEG to the New Mexico Institute of Mining and Technology.

EIS - Environmental Impact Statement, environmental documentation required by federal law (NEPA) (Pub. L. 91-190) for large, federally funded programs

EPA - U.S. Environmental Protection Agency, formed by Congress on December 2, 1970, in Reorganization Plan No. 3 of 1970 (5 U.S.C. 903; 40 CFR 1). In this act, Congress transferred to EPA the tasks of monitoring research, setting standards, and performing enforcement activities related to pollution abatement and control such that the environment could be considered as a single, interrelated system. 
ERDA - Energy Research and Development Agency. a forerunner of the DOE, was formed in 1974 (Pub. L. 93-438).

FEPs - features, events (natural and anthropogenic phenomena of short duration), and processes (natural phenomena of long duration)

GAO - General Accounting Office, U.S. Congress

HLW - High-level (radioactive) waste, ". . . the highly radioactive material [fission products and some actinides,] resulting from the reprocessing of spent nuclear fuel, including liquid waste produced directly in reprocessing and any solid material derived from such liquid waste that contains fission products in sufficient concentrations ..." (NWPA, 1982, \$2[12]) Although not used in this manner in this report, general articles regarding radioactive waste use the term high-level waste to imply any combination of spent nuclear fuel and HLW (and sometimes transuranic [TRU] waste) that requires disposal in a deep, geologic repository. 10 CFR 60 , which was promulgated by the NRC prior to NWPA, also includes spent nuclear fuel in its definition of high-level waste.

HSWA - Hazardous and Solid Waste Amendments of 1984 (Pub. L. 98-616) (see also RCRA)

IAEA - International Atomic Energy Agency, Vienna, Austria, established in 1957 by General Assembly of the United Nations to foster research and development in the peaceful uses of nuclear energy

INEEL - Idaho National Engineering and Environmental Laboratory, a multiprogram laboratory in Idaho Falls, Idaho, furnishing engineering services and products on primarily nuclear energy and related technologies. The Idaho Chemical Processing Plant (ICPP) at the Idaho site processes highly enriched uranium fuel from spent nuclear fuel stored at the site. In addition to receiving spent nuclear fuel from throughout the DOE defense complex, it stores a large volume of TRU waste from Rocky Flats destined for the WIPP. Prior to 1970, it buried this TRU waste, but now stores it on the surface.

IRG - Interagency Review Group on Nuclear Waste Management. The Carter Administration formed this group on the recommendation of Secretary of Energy Schlesinger. The group consisted of the DOE and eight other agencies together with several entities within the Executive Branch, including the Council on Environmental Quality.

LANL - Los Alamos National Laboratory, a multiprogram laboratory in Los Alamos, NM, conducting research and development on all facets of nuclear weapon design and basic research in a variety of areas. A large volume of TRU waste stored on site is destined for the WIPP.

LEAF - Legal Environmental Assistance Foundation, U.S. environmental special interest group

LWA - Waste Isolation Pilot Plant Land Withdrawal Act (Pub. L. 102-579 - 106 Stat. 4777)

MED - Manhattan Engineering District of Army Corps of Engineers; assigned task of developing atomic bomb in 1942

MIT - Massachusetts Institute of Technology

MTHM - metric tons of heavy metal; regulatory mass unit in Title 40 CFR Part 191 where heavy metal is all the uranium, plutonium, and thorium initially placed in a nuclear power reactor

MRS - Monitored Retrievable Storage Facility for spent fuel from commercial power reactors, proposed in 1982 in NWPA and discussed in 1987 in NWPAA (see also RSSF)

NAS - National Academy of Sciences, a private, nonprofit, self-perpetuating society of distinguished scholars engaged in scientific and engineering research. The Academy was chartered by Congress in 1863 with the mandate to advise the federal government on scientific and technical matters.

NEFTRAN - network flow and transport computer program

NEPA - National Environmental Policy Act of 1969, federal law that sets environmental policy by requiring an environmental impact statement on all major federal project (Pub. L. No. 91-190, 83 Stat. 852)

NMED - New Mexico Environment Department.

NRC - Nuclear Regulatory Commission, formed by the 1974 Energy Reorganization Act (Pub. L. 93-438) from the - tomic Energy Commission

NRDC Natural Resources Defense Council, U.S. environmental special interest group

NWPA - Nuclear Waste Policy Act of 1982 provides a national policy for the interim storage, monitored retrievable storage, and eventual disposal of radioactive waste.

NWPAA - Nuclear Waste Policy Amendments Act of 1987, amendments to the Nuclear Waste Policy Act of 1982 specifying that only a repository site at Yucca Mountain was to be characterized by the DOE and placing less emphasis on the monitored retrievable storage option

ORNL - Oak Ridge National Laboratory, Y-12 Plant, Oak Ridge Reservation, Oak Ridge, TN. A large volume of TRU waste in storage is destined for the WIPP.

OTA - Office of Technology Assessment, U.S. Congress 
PA - Performance assessment, the process of assessing whether a system meets a set of performance criteria. For the WIPP PA, the process is a stochastic simulation. The system is a deep geologic repository disposal system (in salt) for DOE TRU waste. The performance criteria are various long-term environmental metrics in U.S. government regulations (not short-term operational safety issues).

PRA - Probabilistic risk assessment, the process of assessing, through a stochastic simulation, the risks from a system. A PRA is identical to a performance assessment (PA) in the United States; however, the connotations of the two terms differ. A PRA usually connotes (a) a system composed solely of human-engineered components, and (b) performance criteria that include risk to health over a short time (e.g., human lifetime) relative to geologic time. A PA usually connotes a system composed of both natural and human-engineered components over geologic time. Because the time frame is different, many phenomena for a PRA can be termed events (short-term phenomena); because the components are all human engineered, measured failure rates of components are often available. The modeling tools in a PRA can include elaborate event and fault trees and can substitute empirical data for mechanistic models. For a WIPP PA, the event trees are simpler, fault trees are not used, and mechanistic models are used directly.

QA - quality assurance, all those planned and systemic actions necessary to provide adequate confidence that a structure, system, or component will perform satisfactorily in service. Quality assurance for a product is ensuring that the product does what it is supposed to do to meet the specifications of the customer. The customer expectation, as related to a performance assessment, is that the analysis results present an adequate view (primarily from a legal standpoint) of the WIPP performance based on currently available data and information.

RCRA - Resource Conservation and Recovery Act of 1976 (Pub. L. 94-580) and, as used herein, subsequent amendments (e.g., HSWA, Hazardous and Solid Waste Amendments of 1984, Pub. L. 98616). RCRA establishes a procedure to track and control hazardous wastes from time of generation to disposal. Regulations in Title 40 CFR Parts 260-281 implement RCRA with respect to hazardous waste and hazardous waste treatment.

RH-TRU - remotely-handled transuranic waste, packaged TRU waste whose external surface dose rate exceeds 200 mrem per hour, but not greater than 1000 rem per hour, and thus must be handled remotely
RSSF - Retrievable Surface Storage Facility for spent nuclear fuel and high-level waste proposed in 1972 by the AEC

RWMC - Radioactive Waste Management Complex, a nuclear waste storage facility for the DOE complex built in 1952 at Idaho National Engineering and Environmental Laboratory (INEEL)

SA - Stipulated Agreement between the State of New Mexico and the DOE

SAB - Science Advisory Board, EPA

SAR - Safety Analysis Report

SNF - spent nuclear fuel, ". . . fuel that has been withdrawn from a nuclear reactor following irradiation, the constituent elements of which have not been

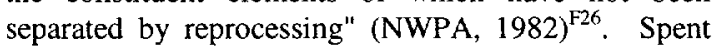
fuel can include intact and failed fuel assemblies, consolidated fuel rods, non-fuel components that are a part of a fuel assembly (such as neutron sources, instrumentation, and fuel channels). Although spent nuclear fuel has fissionable ${ }^{235} \mathrm{U}$, it contains too many radionuclides (primarily short-lived) that adsorb neutrons from the fission process for it to be usefully left in the reactor. Because of spent nuclear fuel's high value, some countries choose to recycle it (recycling becomes more attractive after the short-lived fission products have decayed away). It is also designated separately from other high-level and transuranic wastes in the U.S. Environmental Protection Agency's standard on disposal of radioactive wastes, Title 40 CFR Part 191.

SNL - Sandia National Laboratories, a multiprogram laboratory located in Albuquerque, NM, and Livermore, CA. SNL is operated and managed for the DOE by the Sandia Corporation. From 1949 until October 1993, Sandia Corporation was a wholly owned subsidiary of AT\&T. Sandia Corporation is currently a wholly owned subsidiary of Lockheed Martin Corporation.

SPDV - Site and preliminary design validation phase performed by Bechtel National, Inc.

SPM - System Prioritization Methodology, developed by Sandia in 1994 and 1995 as an attempt to combine probabilistic performance assessment results with decision theory to help prioritize experimental work conducted for the WIPP

SRP - Savannah River Plant Laboratory Production Reactors Defense Waste Processing Facility, located southeast of Augusta, Georgia. A large volume of TRU waste produced and stored on site is destined for the WIPP.

\section{SWCF - Sandia WIPP Central Files}

SWIFT II - Sandia waste isolation flow and transport computer code initially developed in the late 1970 s and updated in the mid $1980 \mathrm{~s}$ 
SWRIC - Southwest Research and Information Center, New Mexico special interest group

TRU - TRansUranic, all elements of the periodic table having atomic numbers greater than 92

TRUPACT-I - Transuranic Package Transport, design $I$, designed to be a vented package in the same shape and size as standard shipping containers to facilitate shipment. The EEG objected to a vented container; so the package was completely redesigned (see TRUPACT-II)

TRUPACT-II - Transuranic Package Transport, design II, designed to be a pressurized hemispherical package for use on flatbed trucks
USGS - U.S. Geological Survey, Department of Interior (DOI)

WIPP - Waste Isolation Pilot Plant, a full-scale research and development repository for transuranic wastes near Carlsbad, NM. WIPP was authorized in 1979 (Pub. L. 96-164) for the management, storage, and eventual disposal of waste generated by DOE defense programs that is contaminated with transuranic radionuclides and some RCRA hazardous chemicals.

WPIO - WIPP Project Integration Office, formed in 1989 , forerunner of the Carlsbad Area Office (CAO)

WPO - WIPP Project office, forerunner of the Carlsbad Area Office (CAO) 


\section{Milestones for Disposal of Radioactive Waste at the Waste Isolation Pilot Plant}

New Mexico has a long history of involvement in nuclear phenomena: In 1942, the Manhattan Engineering District (MED) of the Army Corps of Engineers selected New Mexico for assembling the scientists, engineers, and technicians to develop the first atomic bomb and what was to become Los Alamos National Laboratory and Sandia National Laboratories (SNL). In 1945, the first atomic explosion occurred in the desert near Alamogordo, New Mexico. In 1961, the U.S. detonated a device to explore nonmilitary uses of nuclear explosives in bedded salt near Carlsbad, New Mexico (Gnome Project). ${ }^{\text {T8 }}$ Since 1973, New Mexico has been a potential disposal site for waste contaminated with transuranic (TRU) nuclear elements created during the production of nuclear weapons. ${ }^{77} \mathrm{~A}$ brief description of this latter aspect is presented below followed by a detailed tabulation of milestones of the Waste Isolation Pilot Plant (WIPP).

\section{Early History of Nuclear Waste Disposal Related to the WIPP}

Around 1944, the MED initially decided to bury solid nuclear waste in shallow trenches and augered holes at Los Alamos National Laboratory in New Mexico, and in railroad cars, trenches, and underground caissons at the Hanford Reservation in Washington. Liquid nuclear waste was stored in ponds at both sites. The Atomic Energy Commission (AEC), formed in $1946^{\mathrm{F} 1}$ and the precursor to the Department of Energy (DOE), continued the practices of the MED. The AEC also constructed storage tanks in the late 1940s at Hanford and completed a nuclear waste storage complex at Idaho National Engineering and Environmental Laboratory (INEEL) in 1952.

From 1955 through the late 1960 s, the AEC explored more permanent solutions for radioactive waste disposal in the United States, beginning with its request in 1955 that the National Academy of Sciences (NAS) examine the disposal issue. ${ }^{\mathrm{D} 2}$ In 1957, the NAS reported that while various options and disposal sites were feasible, disposal in salt beds was the most promising method to explore. ${ }^{\text {T3 }}$ The NAS reaffirmed that recommendation in 1961 . Frustration at the lack of a formal waste policy at AEC caused the NAS to strongly criticize AEC disposal practices in $1966 .{ }^{\mathrm{N} 4, \mathrm{~T} 7, \mathrm{~T} 14}$

In 1970, the Board of Radioactive Waste Management of the NAS concluded that bedded salt was satisfactory and was the safest choice then available for nuclear waste disposal. ${ }^{\mathrm{T} 4}, \mathrm{T16}$, T19 From 1961 through the early 1970s, Oak Ridge National Laboratory (ORNL) conducted radioactive-waste disposal experiments, most notably Project Salt Vault in an abandoned salt mine near Lyons, Kansas, from 1963 to $1967 .^{\text {T10, }}$

In May 1969, the Rocky Flats Plant, built by the AEC in 1951 to machine plutonium for nuclear weapons, caught fire. Located only $26 \mathrm{~km}$ (16 mi) from Denver, Colorado, the fire attracted public attention. In its coverage, the press reported that the cleanup waste was eventually to be sent to Idaho. ${ }^{\text {T15 }}$ Idaho state officials voiced concerns that it was becoming the nation's nuclear waste disposal site by default. Hence, the AEC quickly moved to find a more suitable site and tentatively selected the Kansas mine as a repository in June 1970. At the same time, the AEC told Idaho Senator Church that the waste stored in Idaho would be removed by 1980 and sent to the salt mine. ${ }^{\mathrm{D} 7}$ Later in 1970 , a conceptual design was completed for a nuclear waste repository in salt.

Earlier in the year, in March 1970, the AEC had directed that thereafter TRU nuclear waste would be retrievably stored on the surface in Idaho and elsewhere rather than disposed of in trenches with low-level waste. In a related action, the AEC directed in 1971 that high-level waste (HLW) be solidified within five years, stored retrievably at all DOE facilities, and delivered to a federal repository within 10 years. ${ }^{\mathrm{D} 6}$

In the same year, a large number of drill holes and some solution mining were discovered at the proposed repository site near Lyons, Kansas. ${ }^{\text {T15 }}$ Soon after, Congress directed the AEC to stop work on the Lyons project until safety was certified. 
Although the Lyons project was not officially abandoned until 1975, the AEC announced plans in May 1972 for a Retrievable Surface Storage Facility (RSSF). ${ }^{\mathrm{D} 9}$ However, the recently formed U.S. Environmental Protection Agency (EPA) and anti-nuclear groups claimed the RSSF to be de facto permanent disposal, which prompted the AEC to continue searching for a more suitable disposal site. ${ }^{\text {T21-28 }}$

\section{Early Studies at the WIPP*}

With the encouragement of local citizens and the tacit approval of Governor Bruce King, the AEC, ORNL, and the United States Geological Survey (USGS) recommended the extensive salt beds of southeastern New Mexico. ${ }^{\text {T29 }}$ After an initial study of existing information, a potential site near the edge of the basin was identified in 1973 . The first large-scale field test was conducted in March 1974 when ORNL drilled wells AEC-7 and AEC-8. ${ }^{\text {T144 }}$ Also, in 1974, ORNL conducted the first scenario development and deterministic analysis for the proposed repository ${ }^{\mathrm{T} 7}$ although the project was suspended two months later.

In April 1975, SNL was chosen as the lead laboratory to (a) select and characterize, ${ }^{\mathrm{T} 34}$ (b) develop a conceptual design, ${ }^{\text {T40 }}$ (c) draft an environmental impact statement (EIS), ${ }^{\mathrm{D} 1}$ and (d) initiate scientific studies for the repository. ${ }^{\text {T39 }}$ After some site characterization, SNL recommended locating the WIPP site nearer the basin center where the stratigraphy was more predictable. $^{\text {T15, T33, T34 }}$ (A minor repositioning of the disposal panels also occurred in 1982.) The newly positioned site would become the current WIPP repository, near Carlsbad, New Mexico. ${ }^{\text {D11 }}$

National policy issues, court settlements, and negotiated agreements had a strong influence on the amount and type of scientific data collected during the early phase of the WIPP Project. The passage by Congress of the National Environmental Policy Act of $1969^{\mathrm{F3}}$ established a broad national policy requiring an EIS on large

\footnotetext{
*Because the Waste Isolation Pilot Plant (WIPP) Project spans more than 25 years, more events and milestones have occurred than can easily be covered in a few pages; thus, the description is selective to those issues that do not require extensive explanations. However, the large influence of national and regional policy on the type and extent of scientific studies conducted at the site is still evident.
}

federally funded projects. The EIS process exerted its influence during the 1970s as the AEC, which later became the Energy Research and Development Agency (ERDA) and then the $\mathrm{DOE},{ }^{* *}$ continued investigations on bedded salt in general and, specifically, the salt deposit in New Mexico as a satisfactory medium for hosting a repository.

SNL's support of the EIS consisted of (among other things) detailed computer modeling of radioisotope escape through human intrusion and faulting, and the potential transport of radioisotopes through the aquifer overlying the WIPP to the Pecos River over a 250,000-year time frame $\left(\sim 10\right.$ half-lives of $\left.{ }^{239} \mathrm{Pu}\right)$, followed by dose calculations to humans. ${ }^{\text {D1 }}$

During 1978 and early 1979, and without consultation with the State of New Mexico, the mission of the WIPP oscillated between including and excluding commercial spent nuclear fuel (SNF) and HLW in the repository, in addition to TRU wastes. ${ }^{\text {D16. D17 }}$ Also, the new Carter administration required a fresh look at sites and options for nuclear waste disposal. ${ }^{\text {D18-20 }}$

Because some of the examined options created uncertainty about DOE's intentions within the state and were counter to the ideas of some Congressional members, Congress firmly established the purpose of the WIPP Project as a research and development facility for storage and disposal of TRU waste only (i.e., HLW and commercial and defense SNF were excluded). Congress also specifically exempted regulation by the Nuclear Regulatory Commission (NRC) and thus by default granted self-regulation to the DOE. ${ }^{* * *}$ A national advisory group, the WIPP Panel, which was set up under the Board of Radioactive Waste Management of the NAS, ${ }^{\text {D11. }}$ ${ }^{\mathrm{T} 137}$ and an independent state-selected group, the

\footnotetext{
** The Atomic Energy Commission (AEC) was formed by the Atomic Energy Act of $1946{ }^{\mathrm{FJ}}$ The Energy Research and Development Agency (ERDA) and the Nuclear Regulatory Commission (NRC) were formed by splitting the Atomic Energy Commission in the 1974 Energy Reorganization Act ${ }^{\text {FlO }}$ ERDA became the Department of Energy (DOE) in $1977^{\mathrm{F} 16}$

*** Although regulation by the Nuclear Regulatory Commission (NRC) would have been possible, the NRC had been established to regulate primarily commercial nuclear reactors and waste. Also, Congress did not favor NRC oversight of defense-related activities.
} 
New Mexico Environmental Evaluation Group (EEG), were established on the initiative of the DOE to monitor its self-regulation.

After the final EIS ${ }^{\mathrm{D} 1}$ was published in 1980 and a record of decision published in January $1981,{ }^{\text {D24 }}$ the DOE proceeded to the preliminary design of the WIPP. Planning activities included a site and preliminary design validation (SPDV) phase, consisting of drilling two shafts in 1981 and 1982 and mining an experimental area. Full construction of the WIPP surface facility, an extensive underground experimental area, and one underground disposal panel began in 1983 after meeting the terms of the "Consultation and Cooperation Agreement" with the State of New Mexico and continued to completion over the next five years. Simultaneously with design and construction, SNL began fielding many in situ salt creep experiments to characterize the local disposal system. ${ }^{\text {T22, T68, T77 }}$ Although, from a practical standpoint, the predicted and measured values of creep were close, the measured salt creep was nevertheless about three times greater than the predicted values noted in $1985,{ }^{\mathrm{T}}{ }^{1}, \mathrm{~T} 82$ and so by 1989 an alternative mathematical expression for the creep phenomenon was developed. ${ }^{\text {T99 }}$

In addition to developing a general understanding of selected natural phenomena as deemed prudent by SNL scientists (working with peers in waste management) and/or scientists on the WIPP Panel of the NAS, ${ }^{\mathrm{D} 11, \mathrm{~T} 137}$ many of the geotechnical experiments conducted during the 1980s were undertaken to satisfy agreements with the State of New Mexico. Specifically, in 1981 in response to a lawsuit, a "Stipulated Agreement" and the "Consultation and Cooperation Agreement" mentioned earlier were negotiated that defined the relationship of the WIPP Project with the State of New Mexico and listed required geotechnical experiments to be conducted primarily by SNL. ${ }^{\mathrm{N} 8}$

These requirements and early drafts of the EPA nuclear waste disposal regulation in Title 40 of the Code of Federal Regulations Part 191 (40 CFR 191) influenced the type of in situ experiments and activities initially planned at the WIPP. For example, when the WIPP-12 was deepened in 1981 as part of the negotiated settlement with the State of New Mexico, the project encountered a brine reservoir, ${ }^{\mathrm{T} 64}$ which resulted in moving the disposal region $\sim 1800 \mathrm{~m}$ to the south in 1982. By March 1983, SNL and the USGS had examined many of the geotechnical issues. For example, they had explored and dismissed the possibility of extensive dissolution disrupting the repository. ${ }^{\mathrm{T}}$, T70

The decision by Congress in 1987 to characterize only Yucca Mountain, Nevada, for the first commercial SNF and HLW repository ${ }^{\mathrm{F} 35}$ caused the DOE to cancel many of the experiments being performed at the WIPP in support of a potential commercial repository elsewhere in bedded salt. The presence or absence of additional pockets of brine below the repository became of concern to the EEG in the early 1980s. Therefore, some studies were conducted to try to dismiss their presence. ${ }^{\mathrm{T} 4}$ Though the studies strongly suggested brine pockets were not present below the waste rooms in the anhydrite layer in which other brine pockets had been found, the studies were unable to show unequivocally that brine pockets did not occur in deeper anhydrite layers in the Castile Formation. Long-term slow seepage of brine trapped in the salt into the repository became a topic of great interest in $1988,{ }^{\mathrm{N} 16}$ and the full Board of Radioactive Waste Management of the NAS examined the issue. Members of the NAS concluded that rapid salt creep combined with low permeability of the salt meant that the repository would be fairly well consolidated before much brine could enter the repository. ${ }^{\text {T90 }}$

In preparation for the WIPP's planned opening by the end of the 1980s, SNL summarized past work and data, and performed numerous bounding calculations to support a Draft Supplemental EIS in 1989..$^{\text {334, T48 }}$ The summary identified gas generation-the gas being generated through anoxic corrosion of waste containers and degradation of organic materialas an important issue to study. ${ }^{\text {T48 }}$ This issue had been identified in the mid $1970 \mathrm{~s},{ }^{\mathrm{T} 47}$ but it was dismissed based on the assumption that high salt permeability values obtained from measurement in boreholes drilled prior to excavating the repository would allow any gas generated to dissipate without producing large pressures.

Studying gas generation became an important purpose of proposed tests using actual TRU waste within the repository during a monitored pilot phase, after better in situ measurements of the salt permeability within the excavations in the 
mid 1980s suggested values three orders of magnitude less than those measured in the mid 1970s. ${ }^{\text {T90 }}$ However Congress stipulated in 1992 that the waste could be brought to the WIPP prior to demonstrating compliance only if the tests were scientifically necessary. Although the tests would have been potentially reassuring as a demonstration, the monitored pilot phase was not considered a scientific necessity.

Therefore, in October 1993, the NAS recommended $^{\mathrm{T} 124}$ to eliminate the tests with actual waste at the WIPP (pilot phase) and to perform additional experiments in laboratories. ${ }^{\text {D38 }}$ Without a pilot phase, the DOE decided to accelerate to the compliance phase for the WIPP and closed the in situ experimental area in October 1995.

\section{Compliance Setting for the WIPP}

A major task of the WIPP Project, which was initiated about 1986, was developing evidence of compliance. The promulgation of 40 CFR 191 in 1985 established the primary probabilistic regulation with which the WIPP would have to comply. However, a legal ruling in $1984^{\mathrm{F} 30}$ and regulations in 1986 and $1987^{\mathrm{D} 31}$ resulted in defining as much as $60 \%$ of the waste destined for the WIPP as chemically hazardous. This legal ruling established another set of regulations that the WIPP also had to comply with-those for hazardous waste (40 CFR 260-270 and analogous New Mexico regulations) promulgated in response to the Resource Conservation and Recovery Act (RCRA). ${ }^{\mathrm{F} 13}$

In 1992, Congress defined the process by which the WIPP compliance would be evaluated, transferred ownership of the WIPP site to the DOE, and designated the EPA (rather than the DOE) as the regulator of the WIPP (Waste Isolation Pilot Plant Land Withdrawal Act ${ }^{\mathrm{F} 5}$ ). This act officially marked the transition from the construction and disposal-system-characterization phase to the compliance and testing phases. However, these latter phases had begun informally in 1985 and 1986 when the EPA issued $40 \mathrm{CFR} 191^{\mathrm{F} 17}$ and its interpretation of mixed hazardous waste, and in 1989 when SNL first assessed performance using the EPA standard. $^{\mathrm{T} 110, \mathrm{~T} 111}$
Finally, in 1996, the EPA promulgated 40 CFR 194 , a regulation to implement its 40 CFR 191 standard, which imposed several new interpretations, such as expanded human intrusion activities (specifically, potash mining), and requirements, such as peer review on waste characterization, engineered and natural barriers, and conceptual models. ${ }^{\text {F53 }}$ Also in 1996, Congress removed one of the RCRA land disposal requirements (i.e., seeking a nomigration variance), which required calculations similar to those for 40 CFR $191 .{ }^{\mathrm{F} 54}$

\section{Development of Methodology for Assessing Compliance of the WIPP}

The history of assessing performance of a geologic disposal system began formally in 1976 when the ERDA funded two conferences to bring engineers and geologists together to explore the modeling of geologic disposal systems. By 1977, demands for permanent solutions to nuclear waste provided an impetus for President Gerald Ford to request the EPA to more vigorously pursue applicable standards for proposed waste repositories. ${ }^{\mathrm{D} 2, \mathrm{D} 13}$

During the EPA's development of 40 CFR 191 in the late 1970 s and early 1980 s, analysts at SNL were advocates for a thorough approach in evaluating modeling uncertainty (caused by various parameters in models of the exposure pathways and the uncertainty about the various pathways) as a way to gain insight about the behavior of a geologic waste repository. For example, an analysis that SNL had conducted for the EIS had relied heavily on mathematical modeling.

SNL's position on this matter had developed indirectly from participation by a few Sandians on the 60-member team for the Nuclear Reactor Safety Study ${ }^{\mathrm{F} 12}$ and Sandia's direct involvement on several subsequent reactor accident studies for the NRC. In addition, SNL's advocacy for a probabilistic approach was influenced by its use of the approach in evaluating the reliability of weapons systems and also by the growing acceptance externally for evaluating technological risks.

During this period, the term performance assessment (PA) was adopted internationally to 
describe the process of evaluating whether a geologic disposal system complied with the regulatory criteria-criteria that were probabilistic in the United States, thus making the assessment identical to probabilistic risk assessments (PRA) for nuclear reactors.

Performance assessments of systems for the disposal of radioactive wastes nevertheless differed from most simulations used by federal agencies to explore policy options in two significant and related ways. First, in contrast with simulations for policy analysis, the EPA chose to use the PA results for the WIPP ultimately to test compliance of a real system with an existing environmental standard, not merely to gain insight into the behavior of the system. Second, the fact that part of the disposal system was geologic created several differences with some other types of risk assessments. For instance, the geologic portion of the disposal system introduced the necessity to characterize rather than design. Furthermore, geologic components of a waste disposal system are subject to natural processes over geologic time with no discrete failure points; hence, computerimplemented phenomenological models were needed in order to include geologic processes.

In August 1986, SNL accepted DOE's formal request to take responsibility for showing compliance of the WIPP with 40 CFR $1911^{\text {D29, D30 }}$ To gain proficiency and also to enable the project to better adapt efforts to collect information on important processes, SNL conducted four preliminary performance assessments from 1989 through 1992, each one building upon the other. ${ }^{\mathrm{T} 110}$, T111, T116, T117, T121, T125 The use of mathematical models and the general long-term flow path for radioisotope release was similar to the initial EIS, but the simulations were stochastic and numerous complexities were added, such as human intrusion causing radioisotope releases from drill cuttings. Hence, between January 1988 and December 1991, a significant effort was expended in developing a computational modeling system, CAMCON. ${ }^{\text {T3I, }}$ T91, T92, T115 Furthermore, vast numbers of records and documents were produced to ensure that the reasoning behind choices for data and models was traceable and repeatable.

In October 1996, the performance assessment for the Compliance Certification Application (CCA) was submitted to the EPA showing compliance with 40 CFR $191 .^{\text {T135, T136 }}$ While not responsible for evaluating compliance, the NAS also issued a report in October that noted the excellent features of the WIPP site for containing nuclear waste. $^{\text {T137, T138 }}$ These same conclusions were echoed in the 84,000-page second Supplemental EIS issued in November. ${ }^{\mathrm{D} 3}$

Between 1995 and 1997, the EPA and its contractors evaluated the CCA and supporting documentation. ${ }^{\text {F5s }}$ The Conceptual Model Peer Review Group (formed in response to requirements in 40 CFR 194) concluded in early 1997 that 22 of the 24 conceptual models were adequate. The panel thought that, though conservative, the model for spallings (particulates carried to the surface by pressurized gas and/or brine during a hypothetical drilling intrusion in the repository at a future time) lacked sufficient realism; hence, the panel required the model to be redeveloped. The panel also thought the description of the behavior of the magnesium oxide $(\mathrm{MgO})$ backfill needed improvement. During the next few months, more detailed calculations of the spalling phenomenon were run to demonstrate the conservatism of the current model and DOE's commitment to develop a more realistic model before the next certification in five years. ${ }^{\text {T140 }}$ Also, additional information was provided on the behavior of the $\mathrm{MgO}$ backfill such that the Conceptual Model Peer Review Group concluded in an April meeting that these two modeling issues had been resolved. In addition, under the direction of the EPA, the PA calculations were rerun by SNL during the spring and summer, using EPAselected values and distributions for 26 parameters to help bolster EPA confidence in the results.

Finally, in October 1997, the EPA published a draft rule proposing to approve the WIPP. ${ }^{\mathrm{F} 77}$, 558 In May 1998, the EPA issued certification. ${ }^{\mathrm{F} 59}$ In March 1999, Judge Penn lifted his injunction associated with a 1992 lawsuit by the State of New Mexico, and four days later the WIPP received its first shipment of non-RCRA waste. $^{\text {TI42, T143 }}$

\section{Summary}

The opening of the Waste Isolation Pilot Plant on March 26, 1999, was the culmination of a regulatory assessment process that had taken 25 
years. National policy issues, negotiated agreements, and court settlements during the first 15 years of the project had a strong influence on the amount and type of scientific data collected up to this point. Assessment activities before the mid 1980s were undertaken primarily (1) to satisfy needs for environmental impact statements, (2) to satisfy negotiated agreements with the State of New Mexico, or (3) to develop general understanding of selected natural phenomena associated with nuclear waste disposal.
In the last 10 years, federal compliance policy and actual regulations were sketched out, and continued to evolve until 1996. During this period, stochastic simulations were introduced as a tool for the assessment of the WIPP's performance, and four preliminary performance assessments, one compliance performance assessment, and one verification performance assessment were performed. 


\section{Detailed Tabulation of WIPP Milestones}

In the following tabulation of WIPP milestones, the history of the WIPP is divided into four main categories. One category highlights technical milestones, and three categories highlight the major political events that have influenced the WIPP Project, as briefly summarized above. Noteworthy events from all four categories are also shown schematically. The tabulation also indicates two temporal categories of the WIPP Project—one used officially by the DOE for the project as a whole and one used informally by SNL to describe its various activities. 


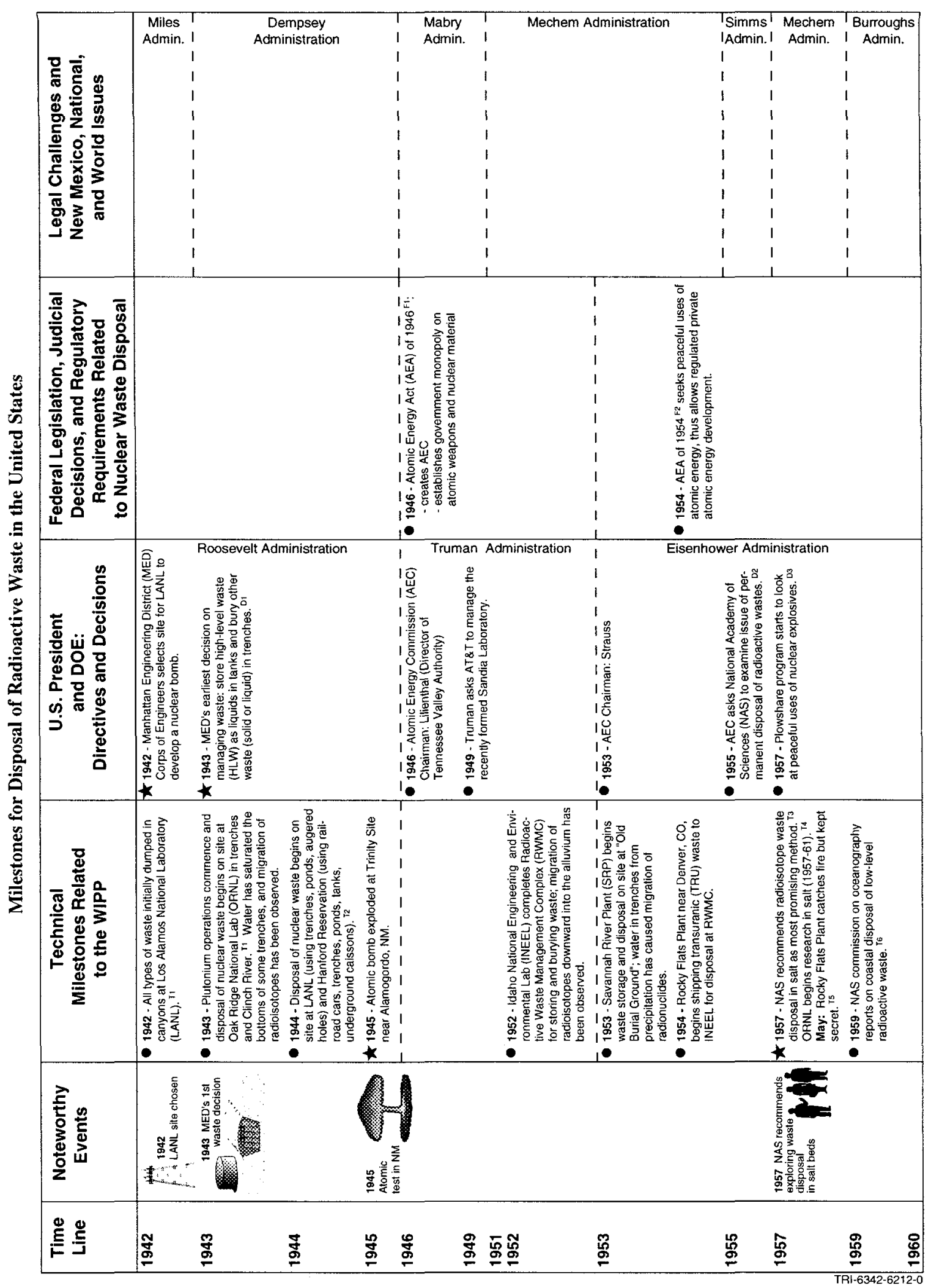




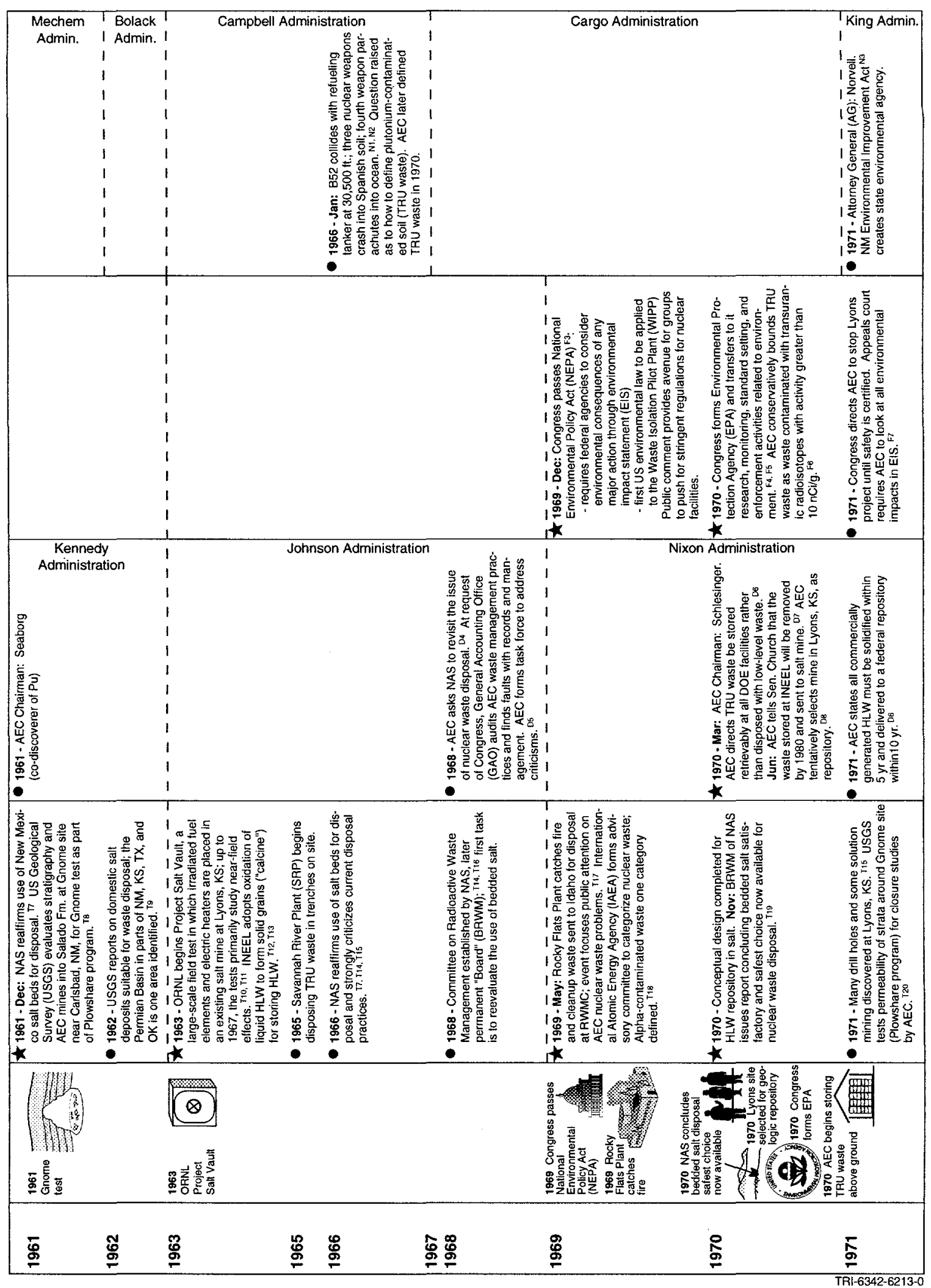


Milestones for Disposal of Radioactive Waste in the United States

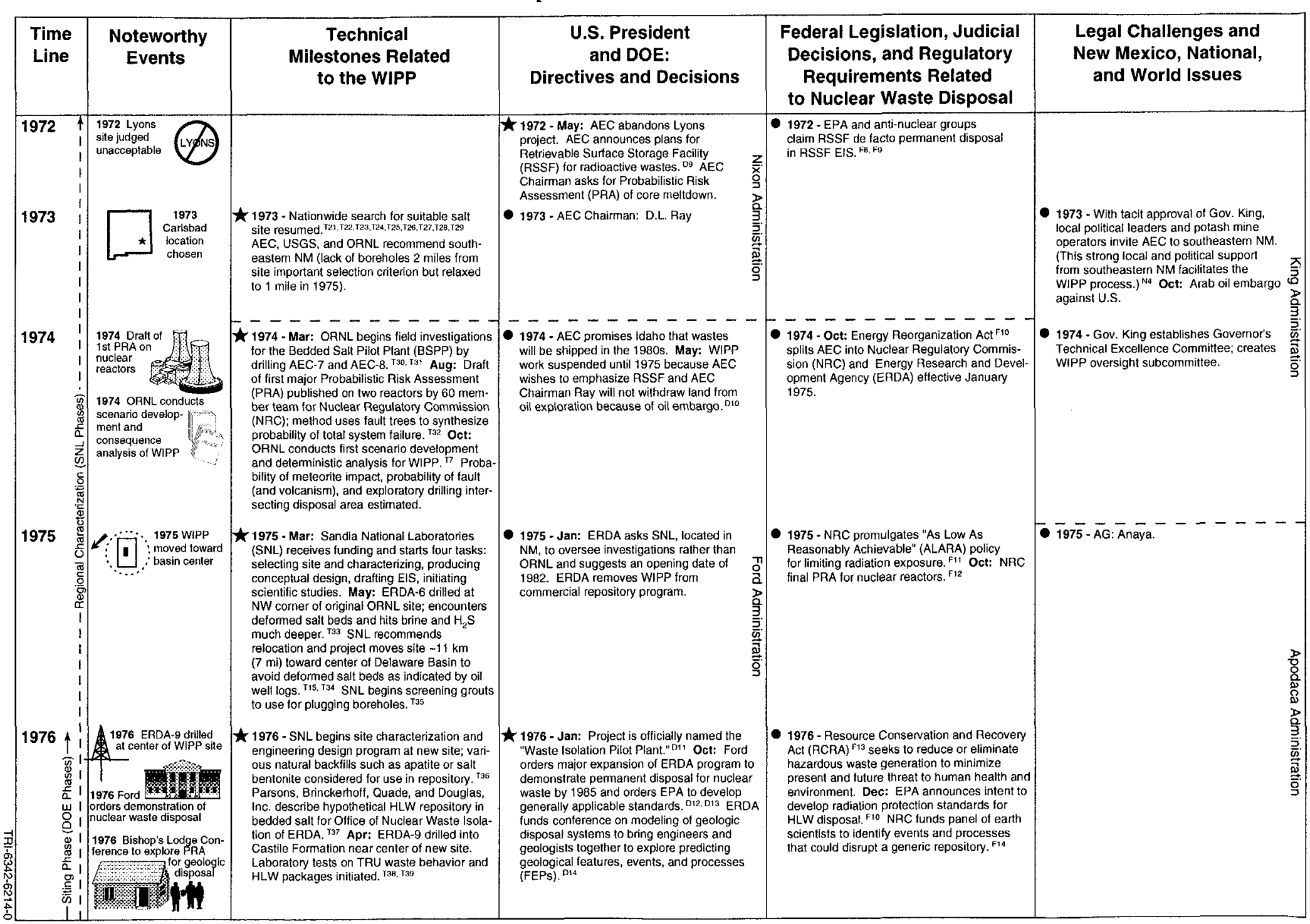




\begin{tabular}{|c|c|c|c|c|c|c|}
\hline 1977 & $\begin{array}{l}7 \\
1 \\
1 \\
1 \\
1 \\
1 \\
1 \\
1 \\
1\end{array}$ & $\begin{array}{l}1977 \text { WIPP conceptual } \\
\text { design with } \\
\text { two } \\
\text { levels }\end{array}$ & 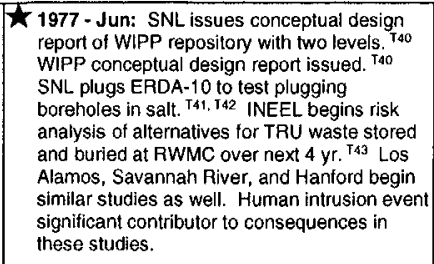 & $\begin{array}{l}\text { 1977-DOE Sec: Schlesinger. Apr: } \\
\text { Carter announces plan to defer indetinitely } \\
\text { reprocessing of commercial spent nuclear } \\
\text { fuel (SNF). D15 Nov: Although role of NRC } \\
\text { at WIPP unclear, DOE tells NRC it plans } \\
\text { to seek license to build and operate WIPP } \\
\text { based on policy trom Carter administration. } \\
\text { (WIPP returns to commercial waste } \\
\text { repository program.) }\end{array}$ & 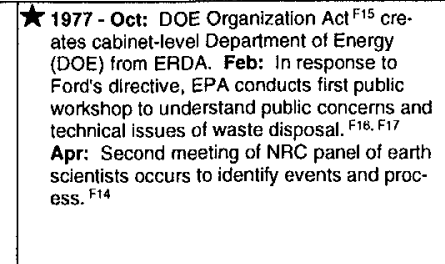 & $\begin{array}{l}\text { - } 1977 \text { - NM Hazardous Waste Act }{ }^{\mathrm{N5}} \text { seeks to } \\
\text { maintain environmental quality. }\end{array}$ \\
\hline 1978 & 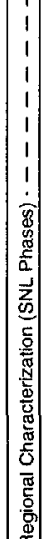 & $\begin{array}{l}1978 \text { Oversight by WIPP } \\
\text { panel o NAS } \\
\text { and NM EEG } \\
\text { begins EEG }\end{array}$ & 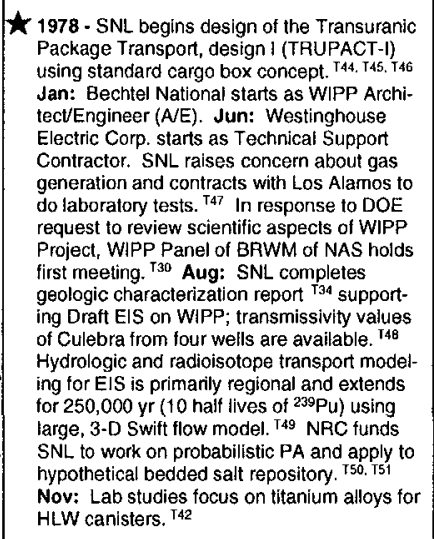 & 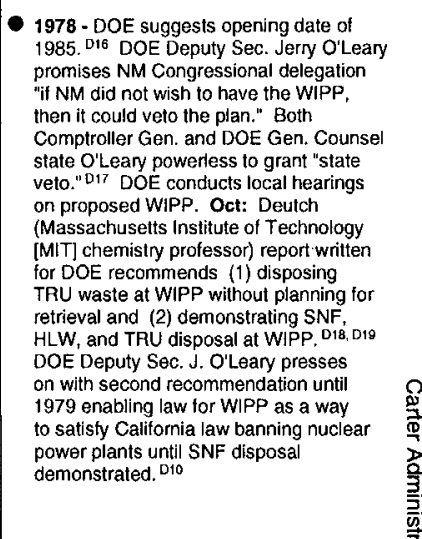 & $\begin{array}{l}\text { - } 1978 \text { - Jan: EPA announces public forum to } \\
\text { develop protection criteria for radicactive } \\
\text { wastes. F18 Nov: EPA publishes "Criteria for } \\
\text { Radioactive Wastes" as guidance for federal } \\
\text { agencies and seeks comments. F19 }\end{array}$ & 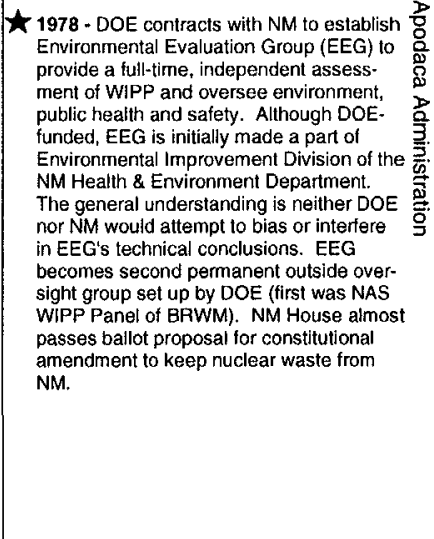 \\
\hline 1979 & 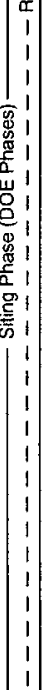 & $\begin{array}{l}1979 \text { Concress defines } \\
\text { mission of WhPP } \\
\text { and passes WiPP } \\
\text { bill for TRU } \\
\text { waste only } \\
\text { 1979 Draft EIS on WIPP } \\
\text { has option for commercial } \\
\text { SSF and conducts } \\
\text { transport analysis } \\
\text { of Pu out to } \\
250,000 \text { yr }\end{array}$ & 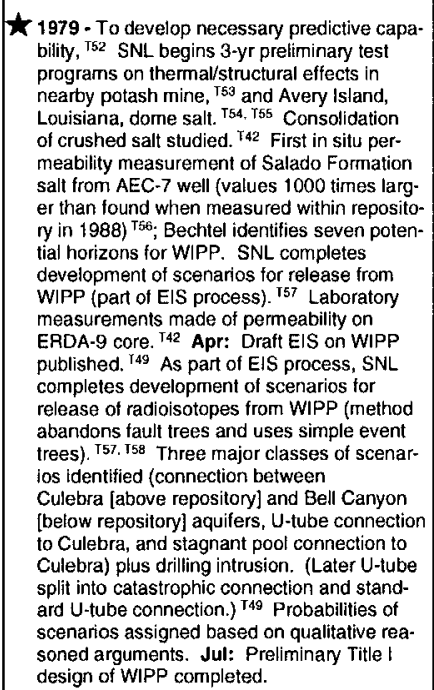 & 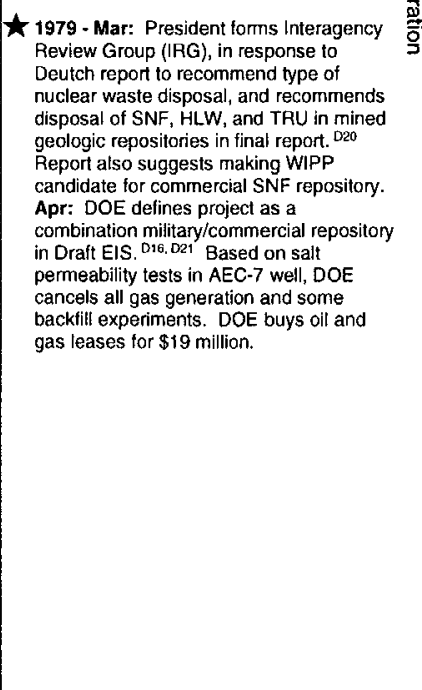 & $\begin{array}{l}\text { 1979 - May: House Armed Services Com- } \\
\text { mittee cuts WIPP funding in response to } \\
\text { O'Leary's (DOE's) expansion of the project } \\
\text { to a repository for commercial SNF and } \\
\text { thus requiring NRC licensing (even if tor } \\
\text { demonstration only). Dec: Congress } \\
\text { defines mission F19 of WIPP: } \\
\text { - sets up WIPP as a research and devel- } \\
\text { opment facility for disposal of only TRU } \\
\text { radioactive waste from DOE facilities } \\
\text { - exempts WIPP from NRC licensing } \\
\text { - requires DOE to sign a "Consultation \& } \\
\text { Cooperation" (C\&C) Agreement with NM. } \\
\text { EPA defines TRU waste as waste with } \\
\text { activity greater than } 100 \text { nCig. }{ }^{2} \text {. }\end{array}$ & $\begin{array}{l}\text { 1979- - AG: Bingaman. Legislature estab- } \\
\text { lishes (1) Governor's Radioactive Waste } \\
\text { Consultation Task Force to negotiate with } \\
\text { DOE and (2) Legislative Radioactive and } \\
\text { Hazardous Materials Committee to review } \\
\text { task force. Ne }\end{array}$ \\
\hline
\end{tabular}


Milestones for Disposal of Radioactive Waste in the United States

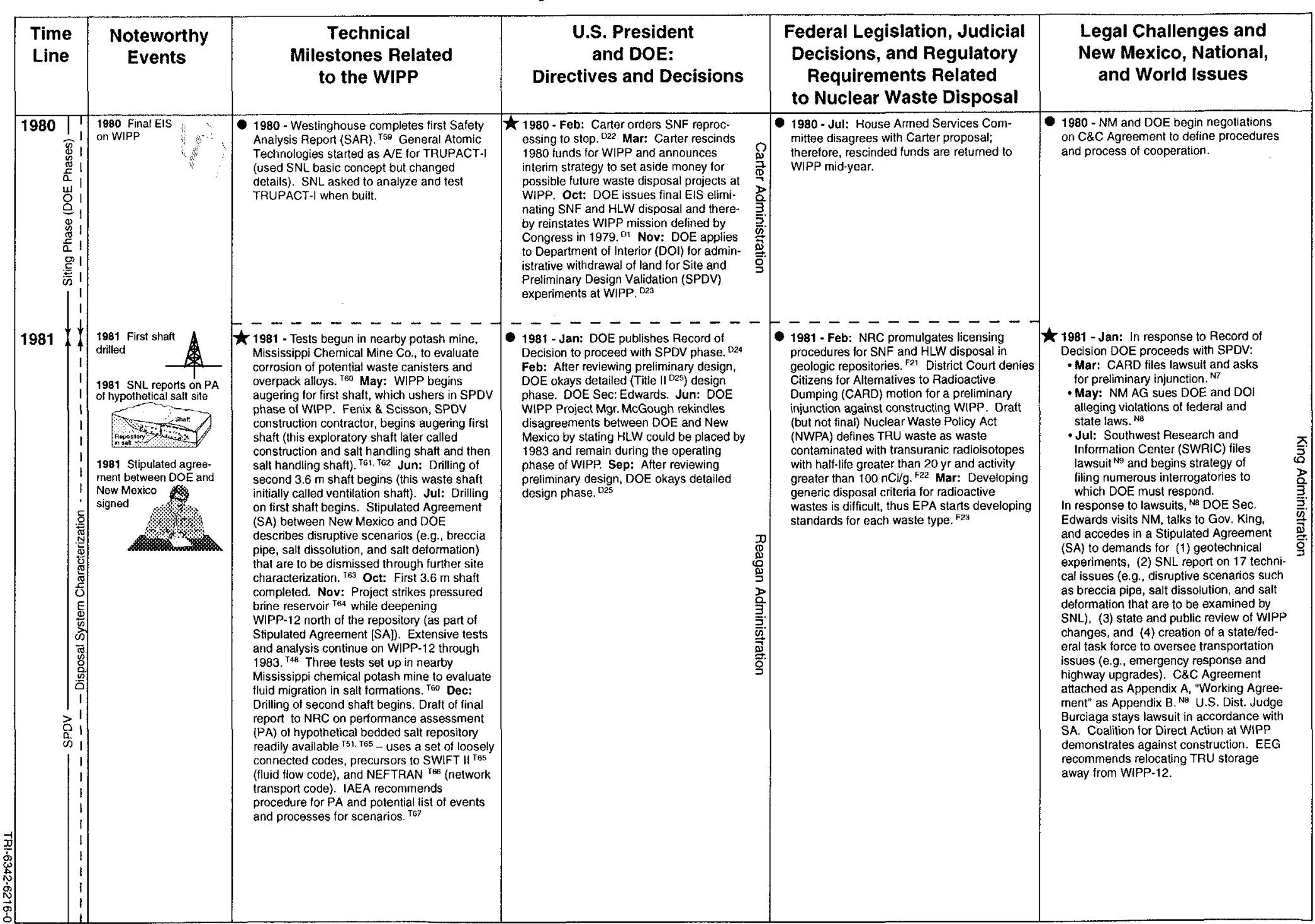




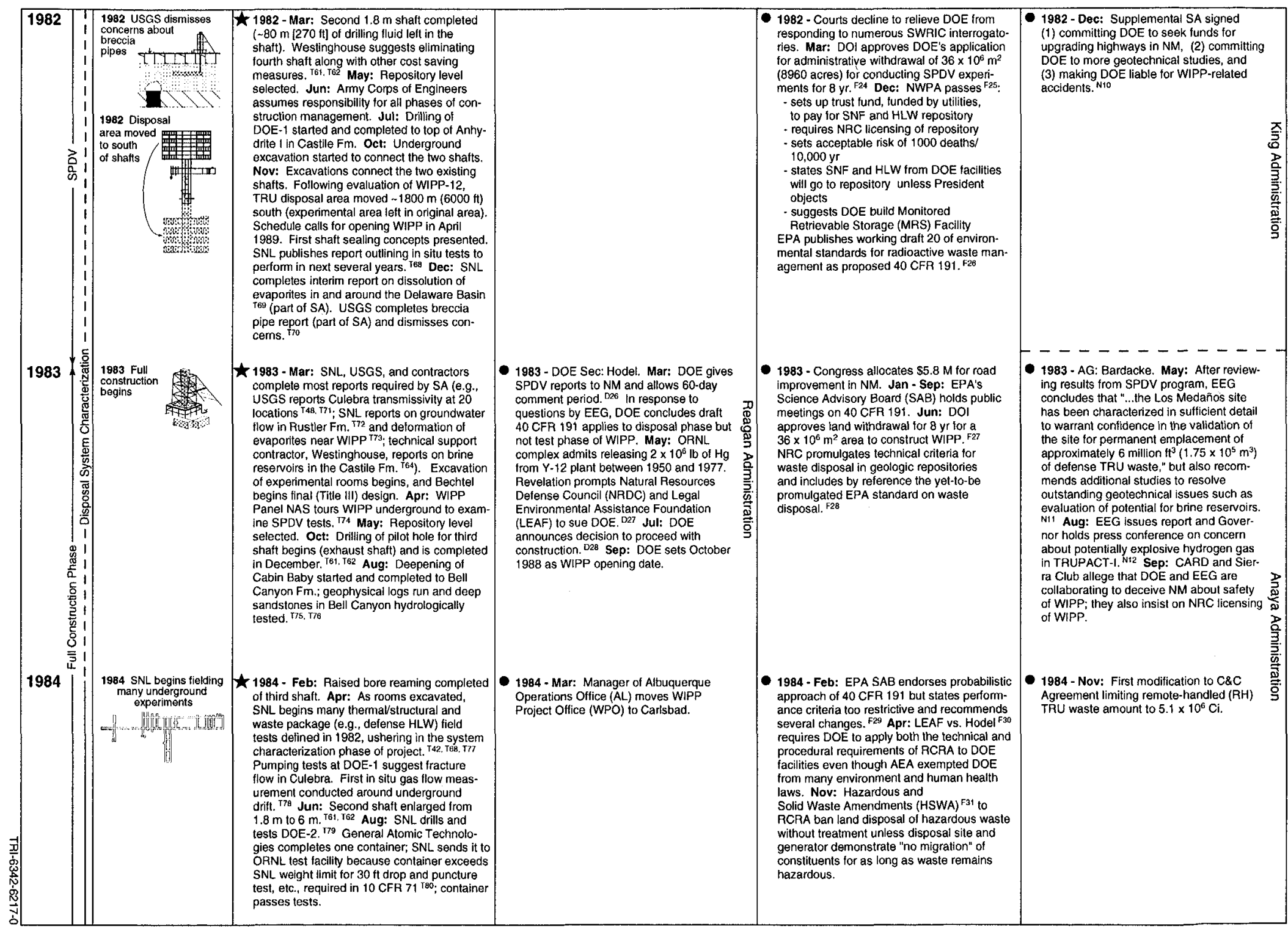


Milestones for Disposal of Radioactive Waste in the United States

\begin{tabular}{|c|c|c|c|c|c|c|}
\hline $\begin{array}{l}\text { Time } \\
\text { Line }\end{array}$ & $\begin{array}{l}\text { Noteworthy } \\
\text { Events }\end{array}$ & $\begin{array}{l}\text { Technical } \\
\text { Milestones Related } \\
\text { to the WIPP }\end{array}$ & $\begin{array}{l}\text { U.S. President } \\
\text { and DOE: } \\
\text { Directives and Decisions }\end{array}$ & $\begin{array}{l}\text { Federal Legislation, Judicial } \\
\text { Decisions, and Regulatory } \\
\text { Requirements Related } \\
\text { to Nuclear Waste Disposal }\end{array}$ & $\begin{array}{l}\text { Legal Challenges and } \\
\text { New Mexico, National, } \\
\text { and World Issues }\end{array}$ & \\
\hline 1985 & $\begin{array}{l}1985 \text { EPA } \\
\text { promulgates } \\
40 \text { CFA 191 }\end{array}$ & 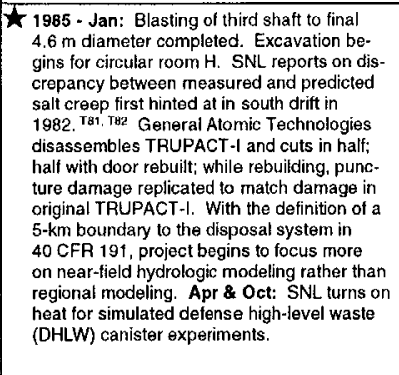 & 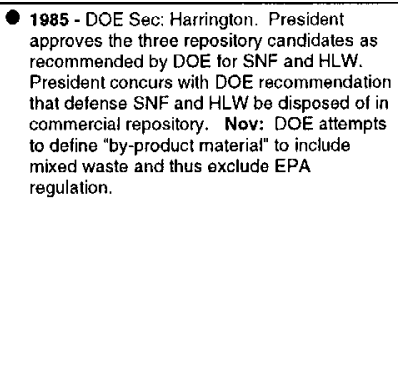 & 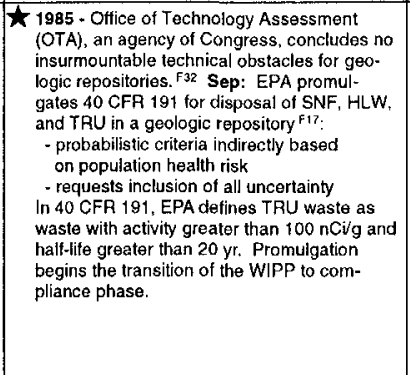 & $\begin{array}{l}\text { - } 1985 \text { - Jan: NM receives EPA authorization } \\
\text { to regulate hazardous wastes. N13 Feb: } \\
\text { Natural Resources Defense Council (NRDC } \\
\text { sues EPA to issue } 40 \text { CFR } 191 \text { as mandate } \\
\text { in NWPA of } 1982 \text {. N14 EEG notities DOE the } \\
\text { the single-shelled, vented rectangular } \\
\text { transportation container for TRU waste, } \\
\text { TRUPACT -1, is unacceptable for NMM. N15 }\end{array}$ & $\begin{array}{l}\text { ion } \\
\text { oc) } \\
\text { ted } \\
\text { hat }\end{array}$ \\
\hline 1986 & 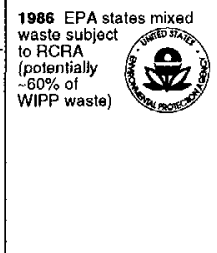 & 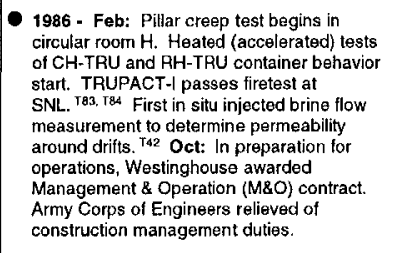 & 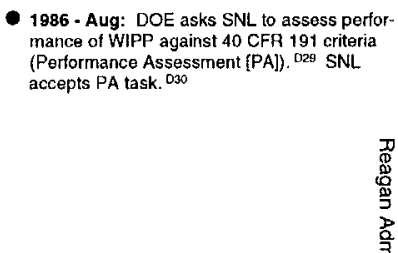 & 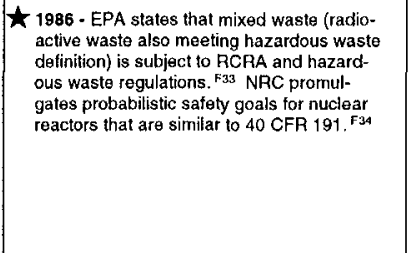 & $\begin{array}{l}\text { - } 1986 \text { - Mar: NRDC and others sue } \\
\text { EPA over groundwater and individual } \\
\text { protection standards in } 40 \text { CFR } 191 \text {. }\end{array}$ & \\
\hline 1987 & $\left\{\begin{array}{l}1987 \\
\text { Brine } \\
\text { pockets } \\
\text { cannot be } \\
\text { dismissed }\end{array}\right.$ & 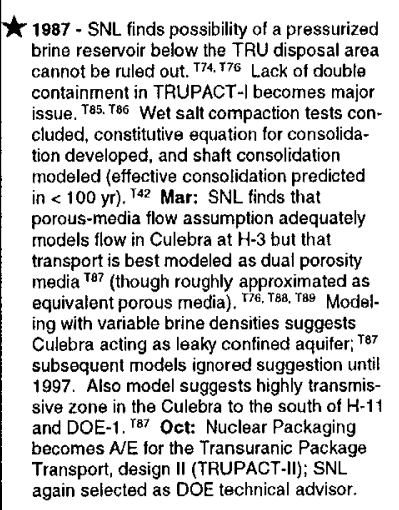 & 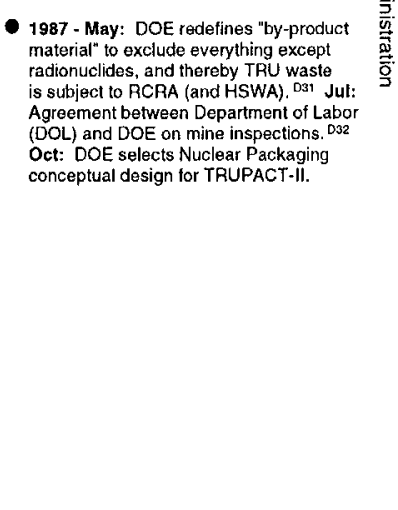 & 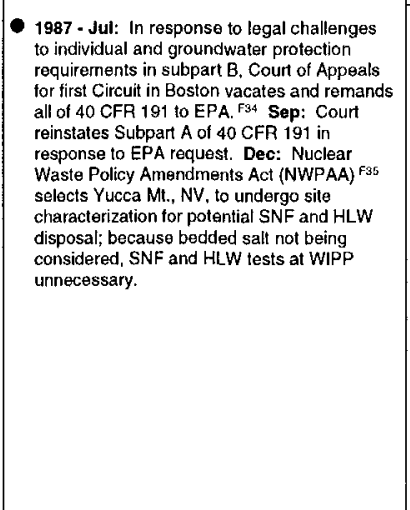 & 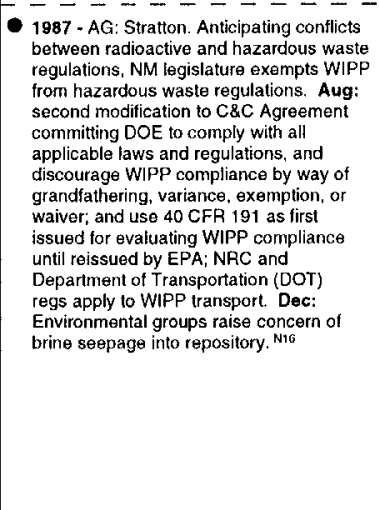 & 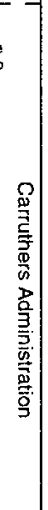 \\
\hline
\end{tabular}




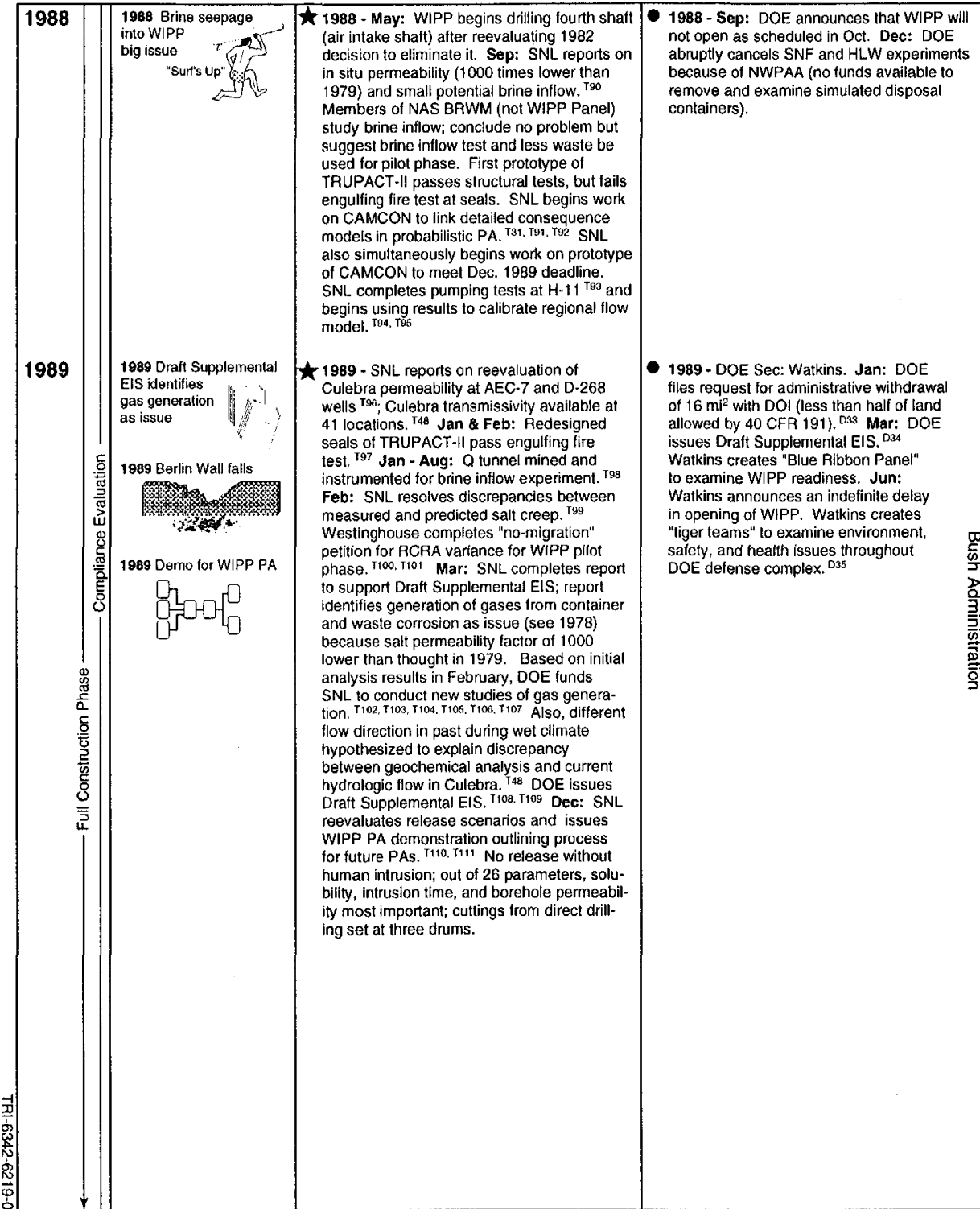

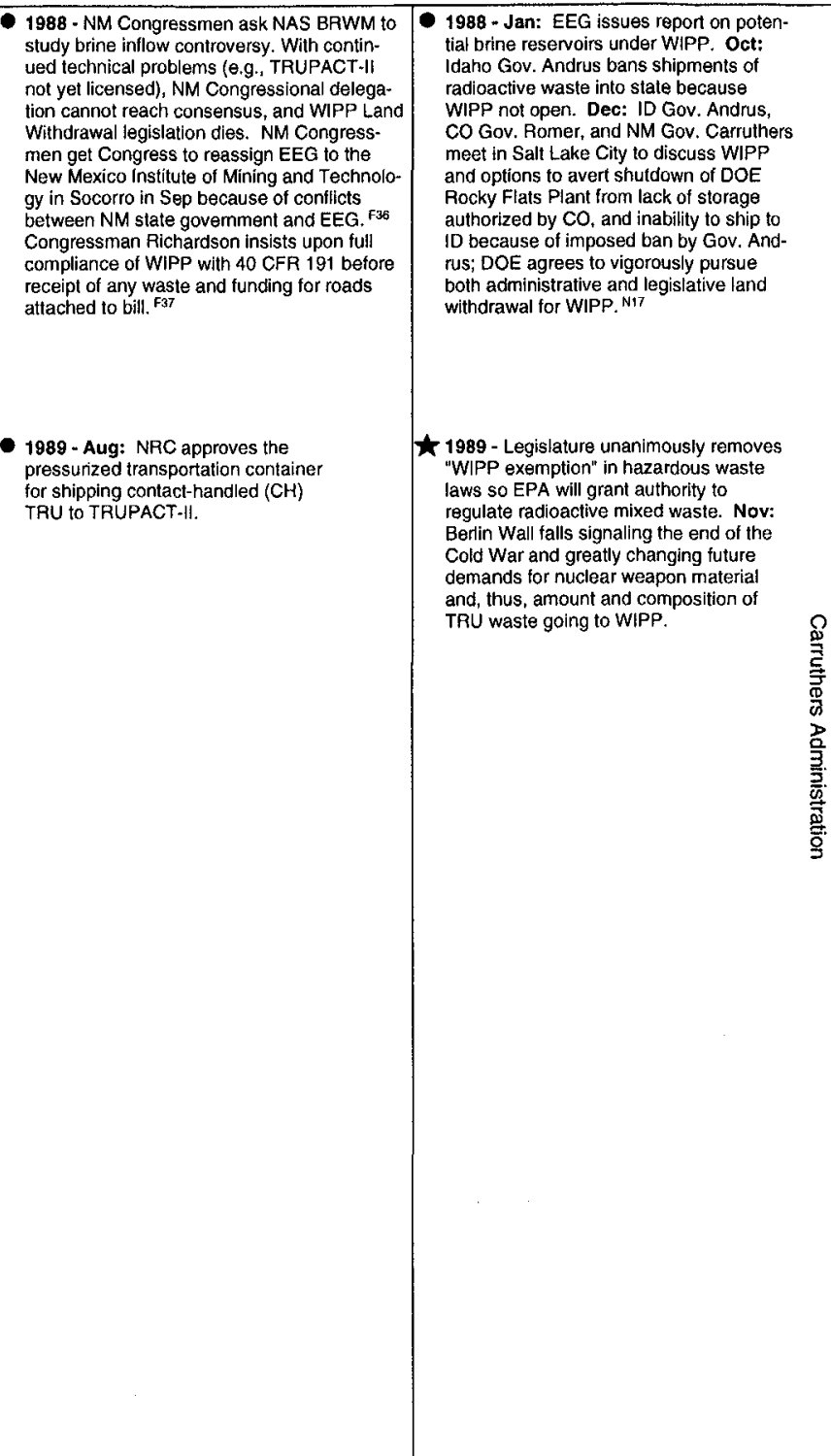


Milestones for Disposal of Radioactive Waste in the United States

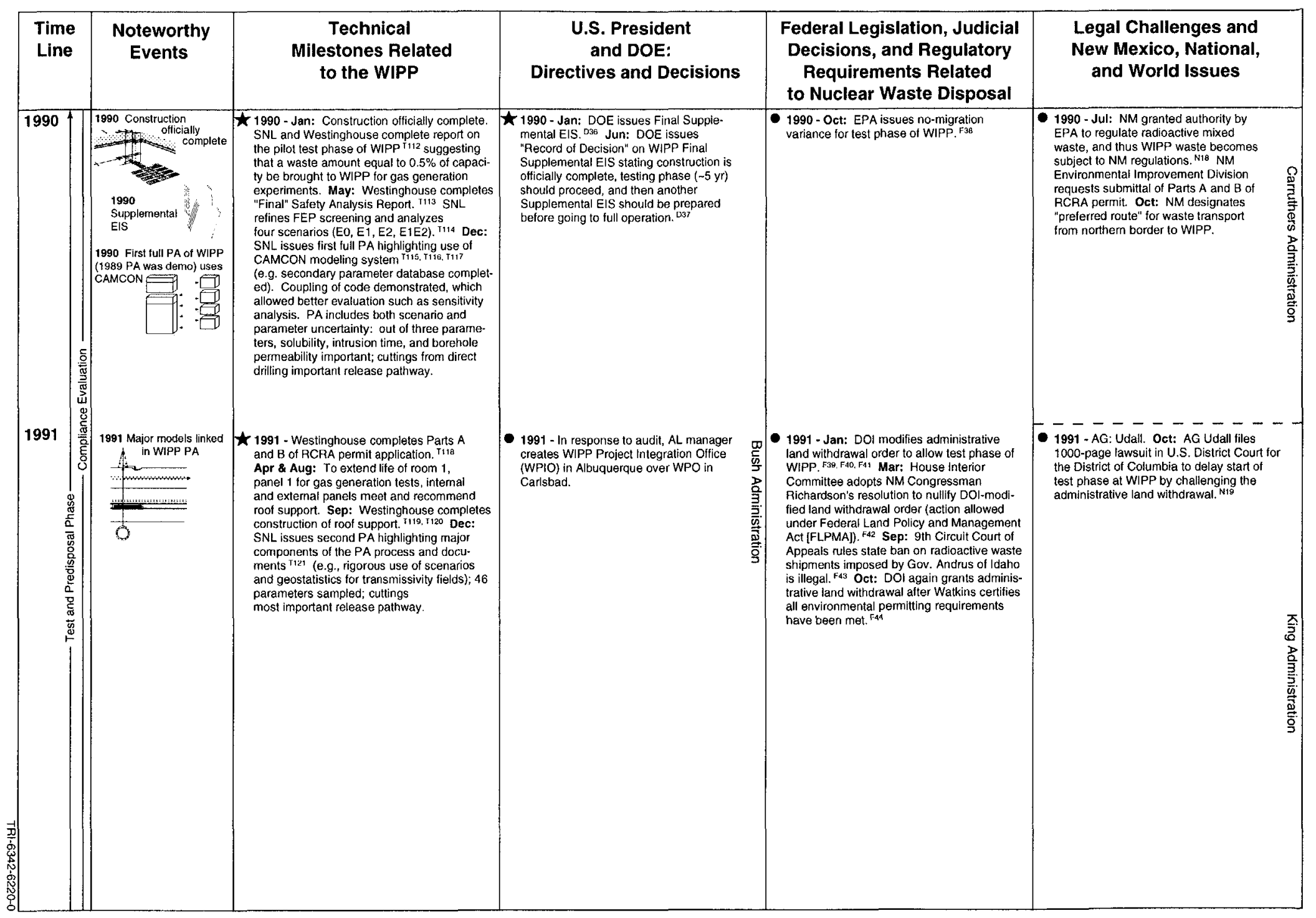




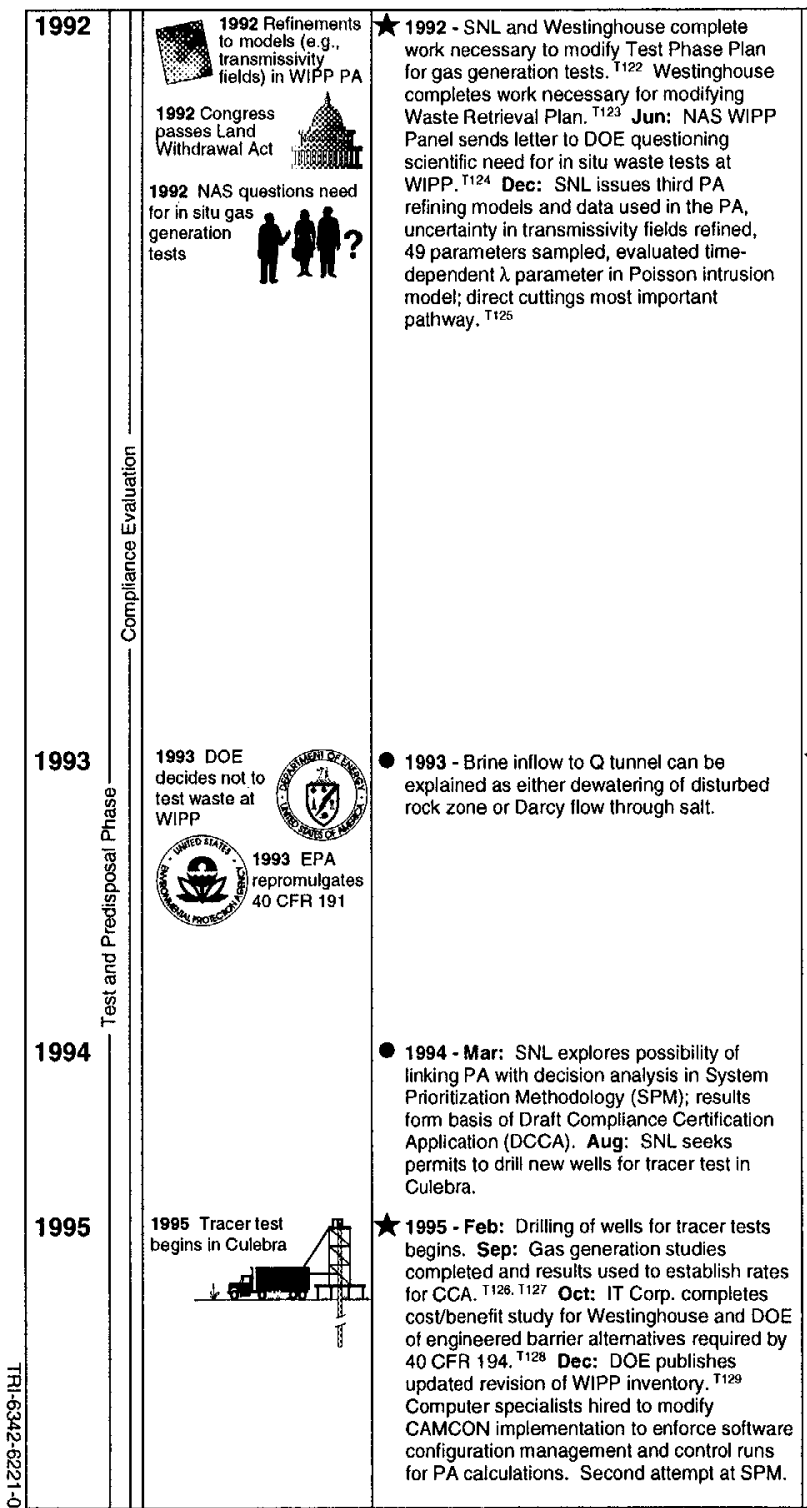

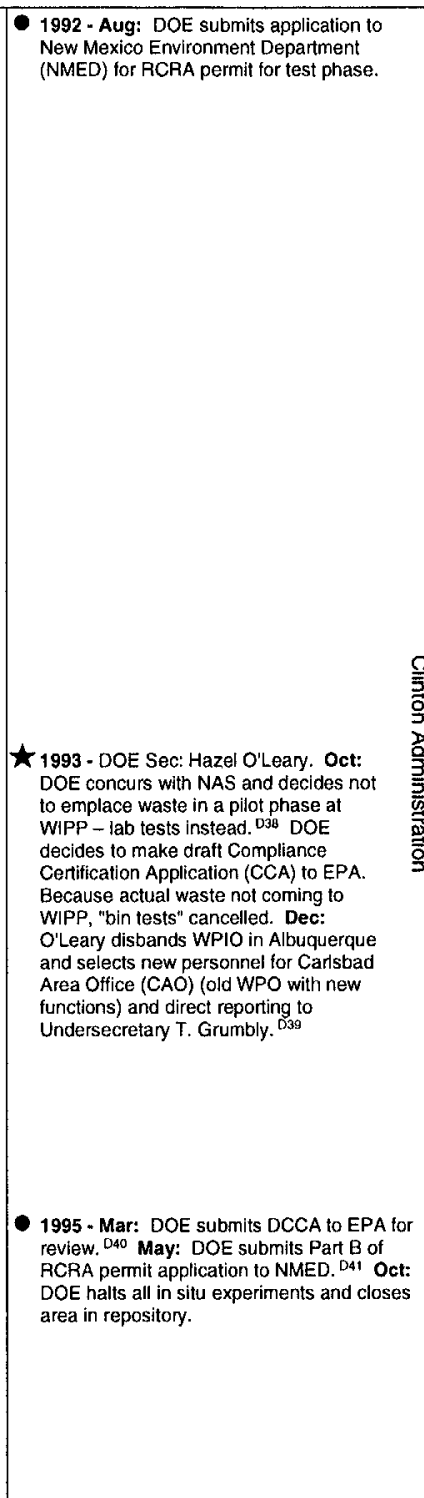
1992 - Oct: WIPP Land Wilhdrawal Act
- transfers land from DOI to DOE establishes EPA as regulator for WIPP (removing selt-regulation by DOE); com- Panel or EEG) to be sel in 40 CFR 194 requires recerrifying site every $5 \mathrm{yr}$ reinstates Subpart B of 40 CFR 191 . except disputed aspects of individual and -requires DOE cooperation and consult- ation with EEG - NM given $\$ 600$ million over $30 \mathrm{yr}$
asks NAS to recommend disposal criteria
quires EPA and NRC to reevaluate Federal Fasility criteria for Yucca M.
- waives federal sovereign immunity for civil and criminal liability for RCRA vio- ations and thus brings DOE facilities Whder junisciction of stales but exempIs Washington DC District Court Judge Penn grants preliminary injunction to stop testing with TRU waste at WIPP. Penn rules WIPP does not quality for interim status under

1993 - Feb: EPA announces intent 10 1993 - Feb: EPA announces intent to
promulgate 40 CFR 194 to specity requirements for implementing 40 CFR 191 at WIPP. F48 Dec: In response to court remand and WIPP LWA, EPA repromulgates
40 CFR 191 to address individual and groundwater protection requirements, and makes other changes - no influential changes for WIPP. ${ }^{448}$

rizes funding for $E E$ tor additional 5 yr. ${ }^{\mathrm{F}} \mathrm{s}$

- 1995 - NAS provides guidance on new regulation for polential Yucca Mt. repository; suggests reporting nisk rrom human inirusion se arately. Jan: EPA proposes compliance cri-
teria for WIPP in 40 CFR 194. 511 May: DOE comments that 40 CFR 194 exceecs 40 CFA 191. Oct: EPA issues draft of nonpinding Compliance Application Gulde (CAG).
- 1992 - Environmental Defense Fund (EDF) and NRDC join the NM lawsult and seet (o. make RCRA issues more importan
(e.g., interim status of WIPP). .220

- 1993 - Mayor Forrest of Carlsbad demands more economic benefits accrue NMED issues Draft RCRA permit for test phase. ${ }^{223}$ 
Milestones for Disposal of Radioactive Waste in the United States

\begin{tabular}{|c|c|c|c|c|c|c|}
\hline $\begin{array}{l}\text { Time } \\
\text { Line }\end{array}$ & $\begin{array}{l}\text { Noteworthy } \\
\text { Events }\end{array}$ & $\begin{array}{l}\text { Technical } \\
\text { Milestones Related } \\
\text { to the WIPP }\end{array}$ & $\begin{array}{l}\text { U.S. President } \\
\text { and DOE: } \\
\text { Directives and Decisions }\end{array}$ & $\begin{array}{l}\text { Federal Legislation, Judicial } \\
\text { Decisions, and Regulatory } \\
\text { Requirements Related } \\
\text { to Nuclear Waste Disposal }\end{array}$ & $\begin{array}{l}\text { Legal Challenges and } \\
\text { New Mexico, National } \\
\text { and World Issues }\end{array}$ & \\
\hline $1997 \mid$ & 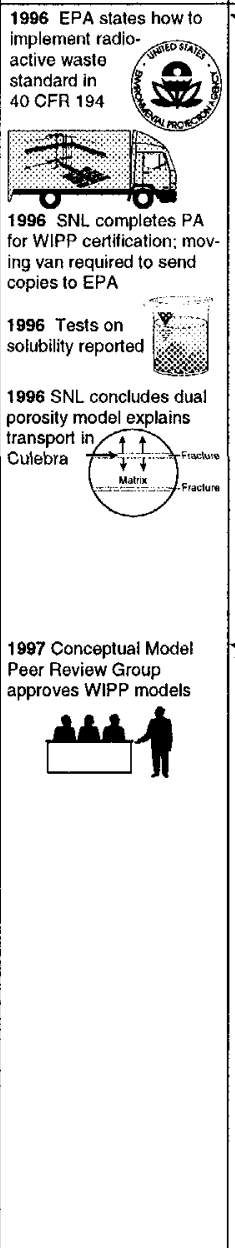 & 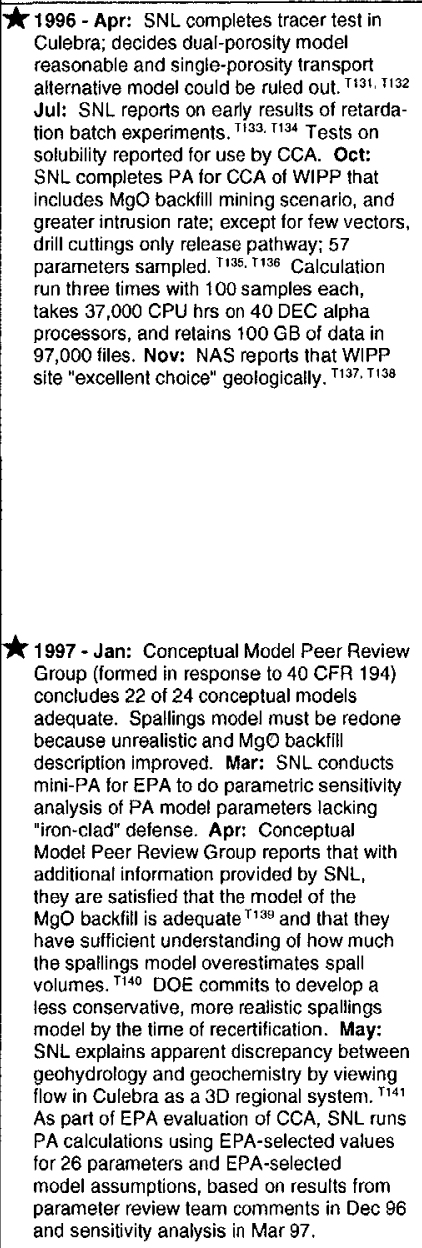 & $\begin{array}{l}\text { - } 1997 \text { - DOE Secretary: Peña. Jan: DOE } \\
\text { holds hearings on second Supplemental } \\
\text { Dratt EIS for WIPP in Carlsbad, Albu- } \\
\text { querque, and Santa Fe, New Mexico. D45 } \\
\text { Sep: Final second Supplemental EIS on } \\
\text { WIPP published. O46 }\end{array}$ & 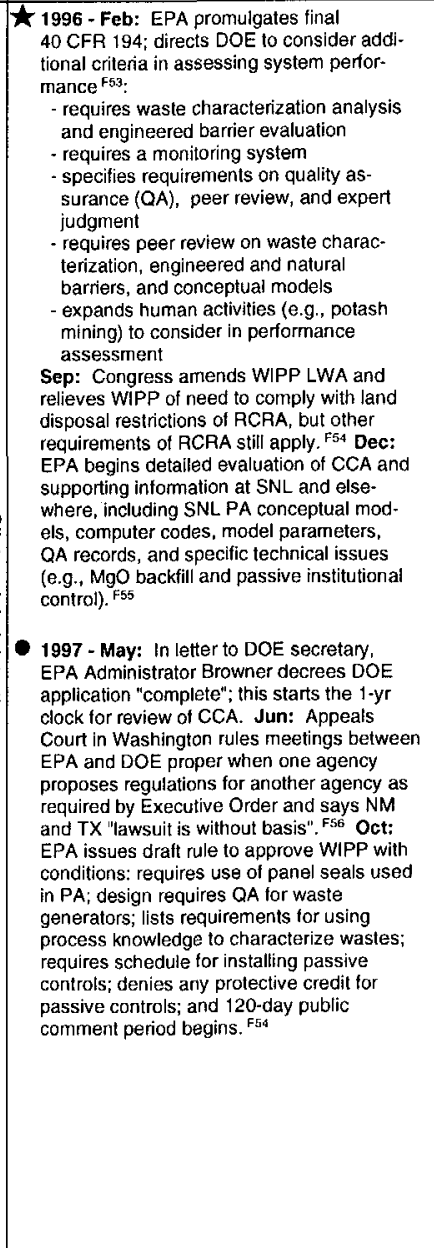 & $\begin{array}{l}\text { - } 1996 \text { - Apr: NM AG Udall sues EPA } \\
\text { alleging improper meetings were } \\
\text { held between EPA and DOE about } \\
\text { requirements in proposed } 40 \text { CFR } 194 \\
\text { regulation. }{ }^{\text {N24 }}\end{array}$ & 产 \\
\hline
\end{tabular}




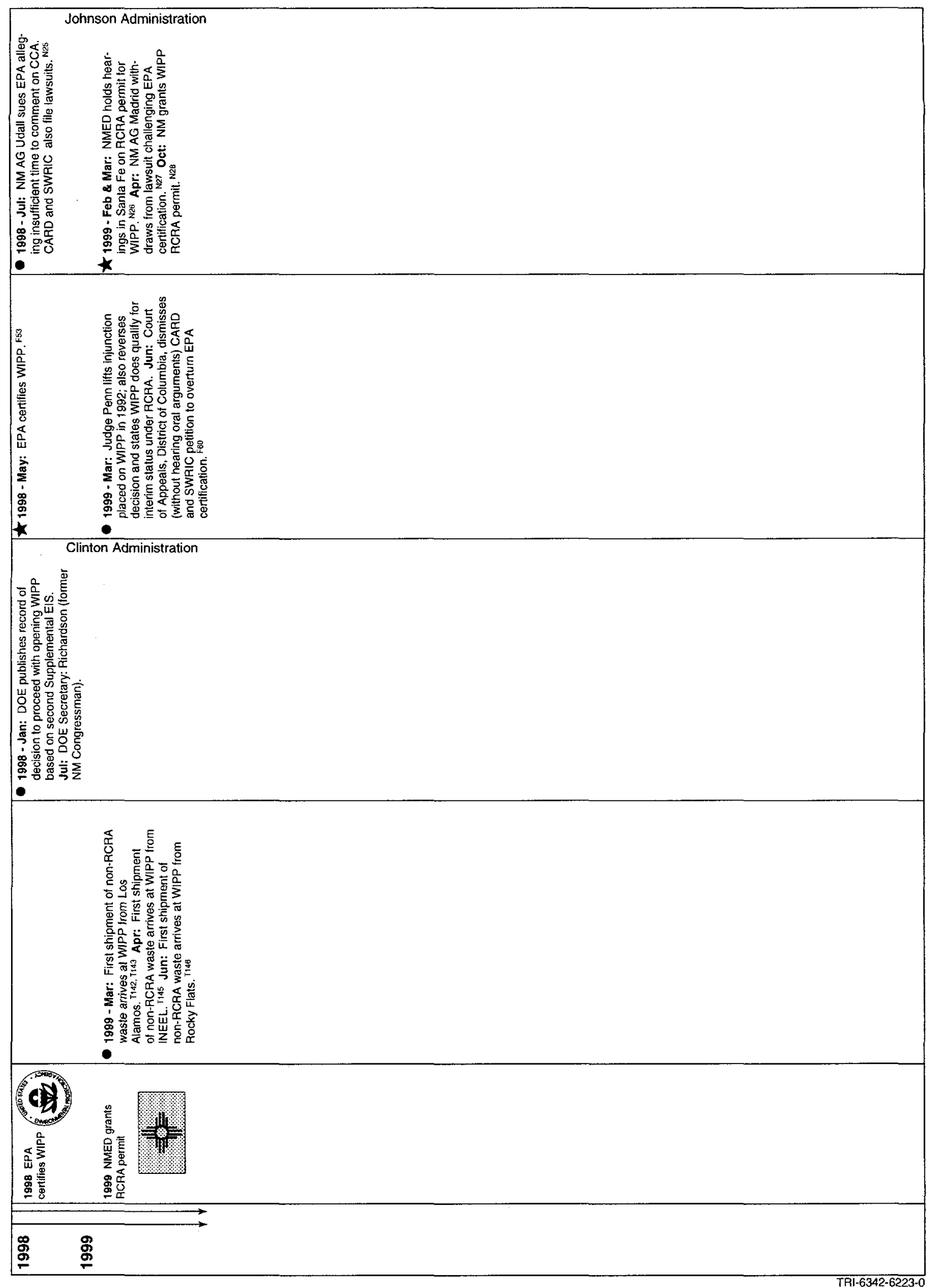




\section{References}

References for U.S. President and DOE: Directives and Decisions

D1 DOE (U.S. Department of Energy). 1980. Final Environmental Impact Statement: Waste Isolation Pilot Plant. DOE/EIS-0026. Washington, DC: U.S. Department of Energy, Assistant Secretary for Defense Programs. Vols. 1-2.

D2 Boffey, P.M. 1975. "Radioactive Waste Disposal: The Atomic Energy Commission Brings the Academy to Heel," The Brain Bank of America: An Inquiry into the Politics of Science. P.M. Boffey. New York, NY: McGraw-Hill Book Company. 89-111, 276278.

D3 Teller, E. 1959. "The Plowshare Program," Proceedings of the Second Plowshare Symposium, San Francisco, CA, May 13-15, 1959. UCRL-5675. Livermore, CA: Livermore Radiation Laboratory. 8-13. (Copy on file in the Sandia WIPP Central Files [SWCF], Sandia National Laboratories, Albuquerque, NM as WPO\#44080.)

D4 EPA (U.S. Environmental Protection Agency). 1985. Background Information Document for Final Rule. High-Level and Transuranic Radioactive Wastes. EPA 520/1-85-023. Washington, DC: Office of Radiation Programs, U.S. Environmental Protection Agency.

D5 Perge, A. 1982. "Historical Overview," Proceedings of Alpha-Contaminated Waste Management Workshop, Gaithersburg, MD, August 10-13, 1982. CONF-820845. Oak Ridge, TN: Oak Ridge National Laboratory. 17-30.

D6 AEC (Atomic Energy Commission). 1970. "Title 10-Atomic Energy Chapter I-Atomic Energy Commission Part 50-Licensing of Production and Utilization Facilities, Siting of Fuel Reprocessing Plants and Related Waste Management Facilities," Federal Register. Vol. 35 , no. $222,17530-17533$.

D7 Lipschutz, R.D. 1980. Radioactive Waste: Politics, Technology, and Risk. Cambridge, MA: Ballinger Publishing Company, A Division of Harper \& Row. 119, 144.

D8 AEC (Atomic Energy Commission). 1971. Environmental Statement: Radioactive Waste Repository, Lyons, Kansas. WASH-1503. [Washington, DC]: United States Atomic
Energy Commission. (Copy on file in the SWCF as WPO\#47929.)

D9 Metlay, D.S. 1978. "History and Interpretation of Radioactive Waste Management in the United States," Essays on Issues Relevant to the Regulation of Radioactive Waste Management. W.P. Bishop, I.R. Hoos, N. Hilberry, D.S. Metlay, and R.A. Watson. NUREG-0412. Washington, DC: Division of Fuel Cycle and Material Safety, Office of Nuclear Material Safety and Safeguards, U.S. Nuclear Regulatory Commission. 6-9.

D10 Carter, L.J. 1987. Nuclear Imperatives and Public Trust: Dealing with Radioactive Waste. Washington, DC: Resources for the Future, Inc.; [Baltimore, MD]: Distributed by John Hopkins University Press. 64-69, 86, 177.

D11 NAS/NRC (National Academy of Sciences/National Research Council). 1984. Review of the Scientific and Technical Criteria for the Waste Isolation Pilot Plant (WIPP). DOE/DP/48015-1. Washington, DC: National Academy Press.

D12 EPA (U.S. Environmental Protection Agency). 1985. "40 CFR Part 191: Environmental Standards for the Management and Disposal of Spent Nuclear Fuel, High-Level and Transuranic Radioactive Wastes; Final Rule," Federal Register. Vol. 50, no. 182, 3806638089.

D13 Ford, G.R. 1976. "The White House Fact Sheet: President's Nuclear Waste Management Plan." October 28, 1976. Washington, DC: Office of the White House Press Secretary. (On file at Gerald R. Ford Library, 1000 Beal Avenue, Ann Arbor, MI, Telephone: 313/7412218.)

D14 Logan, S.E. 1976. Workshop on Geologic Data Requirements for Radioactive Waste Management Assessment Models, Santa Fe, NM, June 28-July 1, 1976. Y/OWI/SUB76/81726, UNM Report No. NE-27(76), Union Carbide 297-1. Albuquerque, NM: University of New Mexico, College of Engineering, Bureau of Engineering Research for Office of Waste Isolation, Union Carbide Corporation, Nuclear Division. (Copy on file in the SWCF as WPO\#52833.)

D15 Sjoblom, G. 1982. "Regulatory Policy of the EPA Related to Alpha-Contaminated Waste," Proceedings of Alpha-Contaminated Waste Management Workshop, Gaithersburg, MD, 
August 10-13, 1982. CONF-820845. Oak Ridge, TN: Oak Ridge National Laboratory. 47-58.

D16 Weart, W.D. 1979. "WIPP: A Bedded Salt Repository for Defense Radioactive Waste in Southeastern New Mexico," Radioactive Waste in Geologic Storage, $176^{\text {th }}$ Annual Meeting of the American Chemical Society, Miami Beach, FL, September 11-15, 1978. Ed. S. Fried. ACS Symposium Series No. 100. SAND78-0934C. Washington, DC: American Chemical Society. 13-36.

D17 McAuliffe, D. 1978. "Licensing Impasse and New Mexico Emotions May Force DOE to Bury WIPP," Nucleonics Week. Vol. 19, no. 36, 2-3.

D18 DOE (U.S. Department of Energy). 1978. Report of Task Force for Review of Nuclear Waste Management. Draft. DOE/ER-0004/D. Washington, DC: U.S. Department of Energy, Directorate of Energy Research.

D19 Carter, L.J. 1978. "Trouble Even in New Mexico for Nuclear Waste Disposal," Science. Vol. 199, no. 4333, 1050-1051.

D20 IRG (Interagency Review Group on Nuclear Waste Management). 1979. Report to the President by the Interagency Review Group on Nuclear Waste Management. TID-29442. Washington, DC: U.S. Department of Energy. (Copy on file in the SWCF as WPO\#47934.)

D21 DOE (U.S. Department of Energy). 1979. Draft Environmental Impact Statement: Waste Isolation Pilot Plant. DOE/EIS-0026-D. Washington, DC: U.S. Department of Energy. Vols. 1-2.

D22 Carter, J.E. 1982. "Appendix A: Presidential Message and Fact Sheet of February 12, 1980," The Politics of Nuclear Waste. Ed. E.W. Colglazier, Jr. New York, NY: Pergamon Press. 220-241.

D23 DOE (U.S. Department of Energy). 1980. "New Mexico; Proposed Withdrawal and Reservations of Lands," Federal Register. Vol. 45, no. 223, 75768-75769.

D24 DOE (U.S. Department of Energy). 1981. "Waste Isolation Pilot Plant (WIPP): Record of Decision," Federal Register. Vol. 46, no. 18, 9162-9164.

D25 DOE (U.S. Department of Energy). 1992. "Definitive Design (Title II)," Project Management System. DOE Order 4700.1. Washington, DC: U.S. Department of Energy.
V-40 through V-41. (Copy on file in the SWCF as WPO\#48333.)

D26 DOE (U.S. Department of Energy). 1983. Summary of the Results of the Evaluation of the WIPP Site and Preliminary Design Validation Program. WIPP-DOE-161. Albuquerque, NM: U.S. Department of Energy. (Copy on file in the SWCF as WPO\#48675.)

D27 LEAF (Legal Environmental Assistance Foundation, Inc.) and Natural Resources Defense Council, Inc., State of Tennessee on behalf of Tennessee Department of Health and Environment (Intervening Plaintiff) v. Donald Hodel, Secretary, United States Department of Energy and United States Department of Energy. No. CIV. 3-83-562. 1984. 586 Federal Supplement 1163. (Copy on file in the SWCF as WPO\#48129.)

D28 DOE (U.S. Department of Energy). 1983. "Announcement of Decision to Proceed with Construction of the Waste Isolation Pilot Plant (WIPP)," Federal Register. Vol. 48, no. 128, 30427-30428.

D29 Krenz, D.L. 1986. Letter dated August 1986 to Evert $\cdot H$. Beckner, Vice President, Energy Programs, Sandia National Laboratories from D.L. Krenz, Assistant Manager for Projects and Energy Programs, DOE Albuquerque Operations Office. (Copy on file in the SWCF as PA00820.)

D30 Beckner, E.H. 1986. Letter dated Aug. 29, 1986, to Mr. Dennis L. Krenz, Assistant Manager to Projects and Energy Programs, DOE Albuquerque Operations Office, E.H. Beckner, Vice President, Energy Programs, Sandia National Laboratories. (Copy on file in the SWCF as PA00820.)

D31 DOE (U.S. Department of Energy). 1987. "10 CFR Part 962 Radioactive Waste-Byproduct Material," Federal Register. Vol. 52, no. 84, 15937-15941.

D32 "Memorandum of Understanding between the U.S. Department of Energy and the U.S. Department of Labor," signed by R.L. Bernard, DOL Administrator for Metal and Nonmetal Mine Safety and Health, and R.G. Romatowski, DOE Manager of Albuquerque Operations Office, dated July 9, 1987. (Copy on file in the SWCF as WPO\#9992.)

D33 EPA (U.S. Environmental Protection Agency). 1982. "40 CFR Part 191: Environmental Standards for the Management and Disposal of Spent Nuclear Fuel, High-Level and Transuranic Radioactive Wastes; Proposed 
Rule," Federal Register. Vol. 47, no. 250, 58196-58206.

D34 DOE (U.S. Department of Energy). 1989. "Waste Isolation Pilot Plant; Availability of Draft Supplement to the Final Environmental Impact Statement," Federal Register. Vol. 54, no. $76,16350-16352$.

D35 McCutcheon, C. 1989. "Embattled WIPP Won't Open in '89," Albuquerque Journal. June 28, 1989. Section A, pages 1, 3 .

D36 DOE (U.S. Department of Energy). 1990. Final Supplement Environmental Impact Statement, Waste Isolation Pilot Plant. DOE/EIS-0026-FS. Washington, DC: U.S. Department of Energy, Office of Environmental Restoration and Waste Management. Vols. 1-13.

D37 DOE (U.S. Department of Energy). 1990. "Record of Decision; Waste Isolation Pilot Plant," Federal Register. Vol. 55, no. 121, 25689-25692.

D38 Anonymous. 1993. "Reversal on Nuclear Waste Tests," Science News. Vol. 144, no. 19 , 303.

D39 McCutcheon, C. 1993. "WIPP Staff Won't Move to Carlsbad," Albuquerque Journal. June 11, 1993. Section D, page 3.

D40 DOE (U.S. Department of Energy). 1995. Draft 40 CFR 191 Compliance Certification Application for the Waste Isolation Pilot Plant.
Phase II Review. DOE/CAO-Predecisional Draft-2056. Carlsbad, NM: U.S. Department of Energy, Waste Isolation Pilot Plant, Carlsbad Area Office. Books 1-2. (Copy on file in the SWCF as WPO\#21135 and WPO\#21136.)

D41 DOE (U.S. Department of Energy). 1995. Resource Conservation and Recovery Act Part $B$ Permit Application. DOE/WIPP 91-005, Rev. 5. Carlsbad, NM: Waste Isolation Pilot Plant. Vols. I-X.

D42 Taugher, M. 1996. "Key WIPP Document Exceeds 400 Lbs," Albuquerque Journal. November 21, 1996. Section D, page 3.

D43 Chiri, T.W. 1996. "Documentation Puts WIPP Opening Closer," Carlsbad Current-Argus. November 21, 1996. Section A, pages 1, 2.

D44 DOE (U.S. Department of Energy). 1996. Waste Isolation Pilot Plant Disposal Phase Draft Supplemental Environmental Impact Statement. November 1996. DOE/EIS-0026S-2. Carlsbad, NM: U.S. Department of Energy, Carlsbad Area Office.

D45 Spohn, L. 1997. "Last Series of WIPP Hearings to Begin Monday," Albuquerque Tribune. January 4, 1997. Section A, page 3.

D46 DOE (U.S. Department of Energy). 1997. Waste Isolation Pilot Plant Disposal Phase Final Supplemental Environmental Impact Statement. DOE/EIS-0026-S-2. Carlsbad, NM: U.S. Department of Energy, Carlsbad Area Office. 
References for Federal Legislation, Judicial Decisions, and Regulatory Requirements Related to Nuclear Waste Disposal

F1 Pub. L. 79-585. 1946. Atomic Energy Act of 1946. (60 Stat. 755). (Copy on file in the SWCF as WPO\#43711.)

F2 Pub. L. 83-703. 1954. Atomic Energy Act of 1954. (68 Stat. 919). (Copy on file in the SWCF as WPO\#43705.)

F3 Pub. L.91-190. 1970. National Environmental Policy Act of 1969. (83 Stat. 852; 42 U.S.C. 4321 et seq.).

F4 EPA (U.S. Environmental Protection Agency). 1993. "Part 1-Statement of Organization and General Information," Code of Federal Regulations 40, Part I. Washington, DC: Superintendent of Documents, U.S. Government Printing Office.

F5 Reorganization Plan No. 3 of 1970. 1970. Federal Register. Vol. 35, no. 194, 1562315626. (5 U.S.C. 903, Paragraph 301, Section 2(a)6; 84 Stat. 2086).

F6 Perge, A. 1982. "Historical Overview," Proceedings of Alpha-Contaminated Waste Management Workshop, Gaithersburg, MD, August 10-13, 1982. CONF-820845. Oak Ridge, TN: Oak Ridge National Laboratory. 17-30.

F7 Pub. L. 93-438. 1974. Energy Reorganization Act of 1974 (88 Stat. 1233; 42 U.S.C. 5801 et seq.).

F8 Carter, L.J. 1987. Nuclear Imperatives and Public Trust: Dealing with Radioactive Waste. Washington, DC: Resources for the Future, Inc.; [Baltimore, MD]: Distributed by Johns Hopkins University Press. 64-69, 86, 177.

F9 MRSRC (Monitored Retrievable Storage Review Commission). 1989. Nuclear Waste: Is There a Need for Federal Interim Storage? Report of the Monitored Retrievable Storage Review Commission. November 1, 1989. Washington, DC: Superintendent of Documents, U.S. Government Printing Office. (Copy on file in the SWCF as WPO\#51784.)

F10 EPA (U.S. Environmental Protection Agency). 1976. "40 CFR Part 260: Environmental Radiation Protection Standards for High-Level Radioactive Waste; Advance Notice of Proposed Rulemaking," Federal Register. Vol. 41 , no. $235,53363$.

F11 NRC (Nuclear Regulatory Commission). 1975. "10 CFR Part 50, Appendix I-Numerical
Guides for Design Objectives and Limiting Conditions for Operation to Meet the Criterion 'As Low as Practicable' for Radioactive Material in Light-Water-Cooled Nuclear Power Reactor Effluents," Federal Register. Vol. 40, no. 87, 19442-19443.

F12 Rasmussen, N.C. 1975. Reactor Safety Study: An Assessment of Accident Risks in U.S. Commercial Nuclear Power Plants. NUREG-75/014, WASH-1400. Washington, DC: U.S. Nuclear Regulatory Commission. (Available from the NTIS as PB-248 200-Set.)

F13 Pub. L. 94-580. 1976. Resource Conservation and Recovery Act of 1976. (90 Stat. 2795 and subsequent amendments; 42 U.S.C. 6901 et seq.).

F14 Krenz, D.L. 1986. Letter dated August 1986 to Evert H. Beckner, Vice President, Energy Programs, Sandia National Laboratories from D.L. Krenz, Assistant Manager for Projects and Energy Programs, DOE Albuquerque Operations Office. (Copy on file in the SWCF as PA00820.)

F15 Pub. L. 95-91. 1977. Department of Energy Organization Act. (91 Stat. 565; 42 U.S.C. 7101 et seq.).

F16 EPA (U.S. Environmental Protection Agency). 1978. "Environmental Protection Criteria for Radioactive Wastes: Announcement of Public Forum," Federal Register. Vol. 43, no. 10, 2223.

F17 EPA (U.S. Environmental Protection Agency). 1985. "40 CFR Part 191: Environmental Standards for the Management and Disposal of Spent Nuclear Fuel, High-Level and Transuranic Radioactive Wastes; Final Rule," Federal Register. Vol. 50, no. 182, 3806638089.

F18 EPA (U.S. Environmental Protection Agency). 1978. "Criteria for Radioactive Wastes; Invitation for Comment: Environmental Protection," Federal Register. Vol. 43, no. 221, 53262-53268.

F19 Pub. L. 96-164. 1979. Department of Energy National Security and Military Applications of Nuclear Energy Authorization Act of 1980. (93 Stat. 1259).

F20 Sjoblom, G. 1982. "Regulatory Policy of the EPA Related to Alpha-Contaminated Waste," Proceedings of Alpha-Contaminated Waste Management Workshop, Gaithersburg, MD, August 10-13, 1982. CONF-820845. Oak 
Ridge, TN: Oak Ridge National Laboratory. 47-58.

F21 NRC (Nuclear Regulatory Commission). 1981. "Disposal of High-Level Radioactive Wastes in Geologic Repositories: Licensing Procedures," Federal Register. Vol. 46, no. 37, 13971-13987.

F22 Freiwald, J. 1982. "Legislature and Political Aspects of Waste Disposal," Proceedings of Alpha-Contaminated Waste Management Workshop, Gaithersburg, MD, August 10-13, 1982. CONF-820845. Oak Ridge, TN: Oak Ridge National Laboratory. 35-38.

F23 EPA (U.S. Environmental Protection Agency). 1985. Background Information Document: Final Rule for High-Level and Transuranic Radioactive Wastes. EPA 520/1-85-023. Washington, DC: Environmental Protection Agency, Office of Radiation Programs.

F24 DOI (U.S. Department of the Interior). Bureau of Land Management. 1982. "43 CFR Public Land Order 6232. New Mexico; Withdrawal of Lands," Federal Register. Vol. 47, no. 61, 13340.

F25 Pub. L. 97-425. 1983. Nuclear Waste Policy Act of 1982. (96 Stat. 2201; 42 U.S.C. 10101 et. seq.).

F26 EPA (U.S. Environmental Protection Agency). 1982. "40 CFR Part 191: Environmental Standards for the Management and Disposal of Spent Nuclear Fuel, High-Level and Transuranic Radioactive Wastes; Proposed Rule," Federal Register. Vol. 47, no. 250, 58196-58206.

F27 DOI (U.S. Department of the Interior). Bureau of Land Management. 1983. "43 CFR Public Land Order 6403. New Mexico; Withdrawal of Lands," Federal Register. Vol. 48, no. 130 , 31038-31039.

F28 NRC (Nuclear Regulatory Commission). 1983. "10 CFR Part 60 Disposal of High-Level Radioactive Wastes in Geologic Repositories: Technical Criteria; Final Rule," Federal Register. Vol. 48, no. 120, 28194-28229.

F29 SAB (EPA Science Advisory Board). 1984. Report on the Review of Proposed Environmental Standards for the Management and Disposal of Spent Nuclear Fuel, High-Level and Transuranic Radioactive Wastes (40 CFR 191). Washington, DC: High-Level Radioactive Waste Disposal Subcommittee, Science Advisory Board, U.S. Environmental Protection Agency.
F30 Legal Environmental Assistance Foundation, Inc. and Natural Resources Defense Council, Inc., State of Tennessee on behalf of Tennessee Department of Health and Environment (Intervening Plaintiff) v. Donald Hodel, Secretary, United States Department of Energy and United States Department of Energy. No. CIV. 3-83-562. 1984. 586 Federal Supplement 1163. (Copy on file in the SWCF as WPO\#48129.)

F31 Pub. L. 98-616. 1984. The Hazardous and Solid Waste Amendments of 1984. (98 Stat. 3221).

F32 U.S. Congress. Office of Technology Assessment. 1985. Managing the Nation's Commercial High-Level Radioactive Waste. OTA-O-171. Washington, DC: Superintendent of Documents, U.S. Government Printing Office. (Copy on file in the SWCF as WPO\#48316.)

F33 EPA (U.S. Environmental Protection Agency). 1986. "State Authorization To Regulate the Hazardous Components of Radioactive Mixed Wastes Under the Resource Conservation and Recovery Act; Notice," Federal Register. Vol. 51, no. 128, 24504-24505.

F34 NRDC (Natural Resources Defense Council, Inc.) v. United States Environmental Protection Agency, et al. 1987. 824 Federal Reporter, $2 d$ Series 1258. (Copy on file in the SWCF as WPO\#43240.)

F35 Pub. L. 100-203. 1987. Nuclear Waste Policy Amendments Act of 1987. (101 Stat. 1330; 42 U.S.C. 10101 et seq.).

F36 Pub. L. 100-456. 1988. National Defense Authorization Act, Fiscal Year 1989. (102 Stat. 1918).

F37 Wieck, P.R., and B. Spice. 1988. "Delegation Buries WIPP Bill for Session," Albuquerque Journal. October 4, 1988. Section A, pp. 1, 3.

F38 EPA (U.S. Environmental Protection Agency). 1990. "Conditional No-Migration Determination for the Department of Energy Waste Isolation Pilot Plant (WIPP)," Federal Register. Vol. 55, no. 220, 47700-47721.

F39 DOI (U.S. Department of the Interior). Bureau of Land Management. 1991. "43 CFR Public Land Order 6826. Modification of Public Land Order No. 6503; New Mexico," Federal Register. Vol. 56, no. 18, 3038-3039.

F40 DOI (U.S. Department of the Interior). Bureau of Land Management. 1991. "Record of Decision (ROD), Waste Isolation Pilot Plant 
(WIPP) Project; New Mexico," Federal Register. Vol. 56, no. 18, 3114-3115.

F41 DOI (U.S. Department of the Interior). Bureau of Land Management. 1991. "43 CFR Public Land Order 6826. Modification of Public Land Order No. 6403; New Mexico," Federal Register. Vol. 56, no. 29, 5731.

F42 Pub. L. 94-579. 1976. Federal Land Policy and Management Act of 1976. (90 Stat. 2743; 43 U.S.C. 1701 et seq.).

F43 State of Idaho, Petitioner, Shoshone-Bannock Tribes, Intervenors, v. U.S. Department of Energy, Respondent, Public Service Company of Colorado, Intervenor. No. 91-70094. United States Court of Appeals, Ninth Circuit. Decided September 20, 1991. 945 Federal Reporter, $2 d$ Series 295. (Copy on file in the SWCF as WPO\#48323.)

F44 DOI (U.S. Department of the Interior). Bureau of Land Management. 1991. "Notice to Proceed, Waste Isolation Pilot Plant (WIPP) Project, New Mexico," Federal Register. Vol. 56, no. 196, 50923-50924.

F45 Pub. L. 102-579. 1992. Waste Isolation Pilot Plant Land Withdrawal Act. (106 Stat. 4777).

F46 Pub. L. 102-486. 1976. Energy Policy Act of 1992. (106 Stat. 2776; 42 U.S.C. 13201 et seq.).

F47 Pub. L. 102-386. 1992. Federal Facility Compliance Act of 1992. (106 Stat. 1505).

F48 EPA (U.S. Environmental Protection Agency). 1993. "Criteria for the Certification of Compliance with Environmental Radiation Protection Standards for the Management and Disposal of Spent Nuclear Fuel, High-Level and Transuranic Radioactive Wastes; Advanced Notice of Proposed Rulemaking," Federal Register. Vol. 58, no. 27, 8029-8030.

F49 EPA (U.S. Environmental Protection Agency). 1993. "40 CFR Part 191: Environmental Radiation Protection Standards for the Management and Disposal of Spent Nuclear Fuel, High-Level and Transuranic Radioactive Wastes, Final Rule," Federal Register. Vol. 58, no. $242,66398-66416$.

F50 Pub. L. 103-160. 1993. National Defense Authorization Act for Fiscal Year 1994. (107 Stat. 1547).

F51 EPA (U.S. Environmental Protection Agency). 1995. "40 CFR Part 194: Criteria for the Certification and Determination of the Waste Isolation Pilot Plant's Compliance With
Environmental Standards for the Management and Disposal of Spent Nuclear Fuel, High-Level and Transuranic Radioactive Wastes; Proposed Rule," Federal Register. Vol. 60, no. 19, 57665791.

F52 EPA (U.S. Environmental Protection Agency). 1995. "Draft Compliance Application Guidance (CAG) Document; Notice of Availability," Federal Register. Vol. 60, no. 201, 53921-53922.

F53 EPA (U.S. Environmental Protection Agency). 1996. "40 CFR Part 194: Criteria for the Certification and Re-Certification of the Waste Isolation Pilot Plant's Compliance With the 40 CFR Part 191 Disposal Regulations; Final Rule," Federal Register. Vol. 61, no. 28, 52245245.

F54 Pub. L. 104-201. 1996. National Defense Authorization Act for Fiscal Year 1997. Subtitle F-Waste Isolation Pilot Plant Land Withdrawal Act Amendments. (110 Stat. 2851).

F55 Nichols, M.D. 1996. "Aspects of the CCA Requiring More Documentation for Completeness and Technical (Particularly Computer Codes) Concerns Before Rulemaking." Recipient: A.L. Alm. Date 12/19/96. Washington, DC: United States Environmental Protection Agency, Office of Air and Radiation. (Copy on file in the SWCF as WPO\#47192.)

F56 Taugher, M. 1997. "Appeals Court Rules WIPP Criteria Meetings OK," Albuquerque Journal. June 7, 1997. Section D, page 3.

F57 EPA (U.S. Environmental Protection Agency). 1997. "40 CFR Part 194: Criteria for the Certification and Re-Certification of the Waste Isolation Pilot Plant's Compliance With the 40 CFR Part 191 Disposal Regulations: Certification Decision; Proposed Rule," Federal Register. Vol. 62, no. 210, 58792-58838.

F58 Taugher, M. 1997. "Agency Finds Disputed WIPP Safe to Open," Albuquerque Joumal. October 24, 1997. Section A, page 1 .

F59 EPA (U.S. Environmental Protection Agency). 1998. "40 CFR Part 194: Criteria for the Certification and Re-Certification of the Waste Isolation Pilot Plant's Compliance With the 40 CFR Part 191 Disposal Regulations: Certification Decision; Final Rule," Federal Register. Vol. 63, no. 95, 27354-27406.

F60 Anonymous. 1999. "Court Tosses Petition Against WIPP License," Albuquerque Journal. July 2, 1999, Section B, p. 1. 
References for New Mexico Administration, Regional Issues, and Legal Challenges

N1 Sandia National Laboratories. 1989. Recollections for Tomorrow. SAND89-1953. Albuquerque, NM: Sandia National Laboratories. 18-19.

N2 Perge, A. 1982. "Historical Overview," Proceedings of Alpha-Contaminated Waste Management Workshop, Gaithersburg, MD, August 10-13, 1982. CONF-820845. Oak Ridge, TN: Oak Ridge National Laboratory. 17-30.

N3 "Environmental Improvement Act," New Mexico Statutes 1978 Annotated (1993 Repl.). Vol. 13, Chapter 74, Article 1, Sections 74-1-1 through 74-1-10. Charlottesville, VA: The Michie Company. (Copy on file in the SWCF as WPO\#47578.)

N4 Carter, L.J. 1987. Nuclear Imperatives and Public Trust: Dealing with Radioactive Waste. Washington, DC: Resources for the Future, Inc.; [Baltimore, MD]: Distributed by Johns Hopkins University Press. 64-69, 86, 177.

N5 "Hazardous Waste Act," New Mexico Statutes 1978 Annotated (1993 Repl.). Vol. 14, Chapter 74, Article 4, Sections 74-4-1 through 74-4-14. Charlottesville, VA: The Michie Company. (Copy on file in the SWCF as WPO\#47585.)

N6 "Article 4A Radioactive Materials," New Mexico Statutes 1978 Annotated (1993 Repl.). Vol. 13, Chapter 74, Article 4A, Sections 744A-1 through 74-4A-19. Charlottesville, VA: The Michie Company. (Copy on file in the SWCF as WPO\#47586.)

N7 SRIC (Southwest Research and Information Center, Inc.). 1981. "Nuclear Waste Disposal," The Workbook. Vol. VI, no. 2, 44. (Copy on file in the SWCF as WPO\#47565.)

N8 State of New Mexico, ex rel., Jeff Bingaman, Attorney General of the State of New Mexico, Plaintiff, v. The United States Department of Energy, et al., Defendants. 1981. "Stipulated Agreement." Civil Action No. 81-0363 JB (United States District Court for the District of New Mexico). July 1, 1981. (Copy on file in the SWCF as WPO\#42008.)

N9 SRIC (Southwest Research and Information Center, Inc.), Peter Montague; Michael Rutherford; Bill Pierce; and June Naylor, Plaintiffs, v. United States Department of Energy; James Edwards, Secretary of the United States Department of Energy; United States Department of Interior; United States Bureau of
Land Management; and Robert F. Burford, Director of the Bureau of Land Management, Defendants. Civil No. 81-0537-JB. United States District Court, District of New Mexico. Action filed July 10, 1981. Judgment rendered October 1, 1984, by U.S. District Judge Juan C. Burciaga. (Copy on file in the SWCF as WPO\#47567.)

N10 Documents Related to State of New Mexico v. U.S. Department of Energy Including the Supplemental Stipulated Agreement Resolving Certain State Off-Site Concerns Over WIPP and the Opinion of the General Counsel of the Department of Energy on Application of the Price-Anderson Act to the Waste Isolation Pilot Plant. 1982. (Copy on file in the SWCF as WPO\#48652.)

N11 Neill, R.H., J.K. Channell, L. Chaturvedi, M.S Little, K. Rehfeldt, and P. Spiegler. 1983. Evaluation of the Suitability of the WIPP Site. EEG-23. Santa Fe, NM: Environmental Evaluation Group, Environmental Improvement Division.

N12 Neill, R.H., and J.K. Channell. 1983. Potential Problems from Shipment of High-Curie Content Contact-Handled Transuranic (CH-TRU) Waste to WIPP. EEG-24. Santa Fe, NM: New Mexico Health and Environment Department, Environmental Evaluation Group.

N13 EPA (U.S. Environmental Protection Agency). 1985. "40 CFR Part 271: New Mexico; Decision on Final Authorization of State Hazardous Waste Management Program: Notice of Final Determination on New Mexico's Application for Final Authorization," Federal Register. Vol. 50, no. 8, 1515-1516.

N14 NRDC (Natural Resources Defense Council, Inc.) v. United States Environmental Protection Agency, et al. 1987. 824 Federal Reporter, $2 d$ Series 1258. Nos. 85-1915, 86-1096 to 861098. United States Court of Appeals, First Circuit. July 17, 1987. As Amended August 12, 1987. (Copy on file in the SWCF as WPO\#43240.)

N15 Channell, J.K., J.C. Rodgers, and R.H. Neill. 1986. Adequacy of TRUPACT-I Design for Transporting Contact-Handled Transuranic Wastes to WIPP. EEG-33. Santa Fe, NM: New Mexico Health and Environment Department, Environmental Evaluation Group.

N16 Begley, S., and M. Miller. 1987. "A Nuclear Dump Springs a Leak," Newsweek. Vol. 110, no. 26,65 . 
N17 Cummings, R.G. 1988. New Mexico Waste Isolation Pilot Project (WIPP): An Historical Overview. DOE/NV/10461-T15. Albuquerque, NM: University of New Mexico for State of Nevada, Agency for Nuclear Projects/Nuclear Waste Project Office. 9-11. (Copy on file in the SWCF as WPO\#47158.)

N18 EPA (U.S. Environmental Protection Agency). 1990. "40 CFR Part 271: State of New Mexico: Final Authorization of State Hazardous Waste Management Program; Final Rule," Federal Register. Vol. 55, no. 133, 28397-28398.

N19 State of New Mexico, ex rel., Tom Udall, Attorney General, Plaintiff, Natural Resources Defense Council, et al., and State of Texas, ex rel., Dan Morales, Attorney General, PlaintiffsIntervenors, v. James D. Watkins, Secretary of the Department of Energy, et al., Defendants. Environmental Defense Fund, et al., Plaintiffs, v. James D. Watkins, Secretary of the Department of Energy, et al., Defendants. Civ. A. Nos. 91-2527, 91-2929. United States District Court, District of Columbia. December 13, 1991. 783 Federal Supplement 628.

N20 State of New Mexico, ex rel., Tom Udall, Attomey General, Plaintiffs, Natural Resources Defense Council, et al., and State of Texas, ex rel., Dan Morales, Attorney General, PlaintiffsIntervenors, v. James D. Watkins, Secretary of Energy, et al., Defendants. v. James D. Watkins, Secretary of the Department of Energy, et al., Defendants. Civ. A. No. 91-2527, 91-2929. United States District Court, District of Columbia. February 3, 1992. 783 Federal Supplement 633.
N21 McCutcheon, C. 1993. "WIPP Staff Won't Move to Carlsbad," Albuquerque Journal. June 11, 1993. Section D, page 3 .

N22 Welch, B. 1993. "Local Group to Meet Energy Secretary over WIPP Standstill," Carlsbad Current-Argus. August 23, 1993. Section A, pages $1,2$.

N23 NMED (New Mexico Environment Department). 1993. Resource Conservation and Recovery Act Draft Hazardous Waste Facility Permit Waste Isolation Pilot Plant (WIPP). EPA I.D. Number NM4890139088. [Santa Fe, NM]: New Mexico Environment Department. Vols. 1-4. (Copy on file at Zimmerman Government Publications, University of New Mexico, Albuquerque, NM as \#E 1.28:DOE/WID 93-RCRA/DRAFT.)

N24 Eichstaedt, P. 1996. "Udall: WIPP Unsafe, Lawsuit Alleges EPA Eased Rules," Albuquerque Journal. April 9, 1996. Section $\mathrm{C}$, page 3 .

N25 Anonymous. 1999. "Opponents: WIPP Must Wait," Albuquerque Journal. January 26, 1999, Section D, p. 1.

N26 Ferry, B. 1999. "Hearings on WIPP Permit Start Monday," Santa Fe New Mexican. February 18, 1999, Section B, p. 1.

N27 Anonymous. 1999. "State Withdraws from Suit Over EPA Certification of WIPP," Las Cruces Sun-News. May 6, 1999, Section A, p. 5.

N28 Parker-Stevens, V. 1999. "WIPP Gets Hazardous Waste Permit from State," Carlsbad Current-Argus. October 28, 1999, Section A, pp. 1,8 . 
References for Technical Milestones Related to the WIPP

T1 AEC (Atomic Energy Commission). 1948. Report of the Safety and Industrial Health Advisory Board. April 2, 1948. Washington, DC: United States Atomic Energy Commission.

T2 Hacker, B.C. 1987. The Dragon's Tail: Radiation Safety in the Manhattan Project, 1942-1946. Berkeley, CA: University of California Press. 4, 5, 69-73

T3 NAS/NRC (National Academy of Sciences/National Research Council). 1957. The Disposal of Radioactive Waste on Land: Report of the Committee on Waste Disposal of the Division of Earth Sciences. Publication 519. Washington, DC: National Academy of Sciences/National Research Council. (Copy on file in the SWCF as WPO\#41159.)

T4 U.S. Congress. 1970. "National Academy of Sciences-National Research Council," Congressional Record. Vol. 116, pt. 10, 1357013589.

T5 Mongan, T.R., S.R. Ripple, G.P. Brorby, and D.G. diTommaso. 1996. "Plutonium Releases from the 1957 Fire at Rocky Flats," Health Physics. Vol. 71, no. 4, 510-521.

T6 NAS/NRC (National Academy of Sciences/National Research Council). 1959. Radioactive Waste Disposal into Atlantic and Gulf Coastal Waters. Publication 655. Washington, DC: Working Group of the Committee on Oceanography of the National Academy of Sciences - National Research Council. (Copy on file in the SWCF as WPO\#47431.)

T7 Claiborne, H.C., and F. Gera. 1974. Potential Containment Failure Mechanisms and Their Consequences at a Radioactive Waste Repository in Bedded Salt in New Mexico. ORNL-TM-4639. Oak Ridge, TN: Oak Ridge National Laboratory. (Copy on file in the SWCF as WPO\#41224.)

T8 Gard, L.M. 1968. Geologic Studies, Project Gnome, Eddy County, New Mexico. Geological Survey Professional Paper 589. Washington, DC: U.S. Department of the Interior [Geological Survey; For Sale by the Superintendent of Documents], U.S. Government Printing Office. (Copy on file in the SWCF as WPO\#48945.

T9 Pierce, W.G., and E.I. Rich. 1962. Summary of Rock Salt Deposits in the United States as Possible Storage Sites for Radioactive Waste
Materials. Geological Survey Bulletin 1148. Washington, DC: Geological Survey. (Copy on file in the SWCF as WPO\#48688.)

T10 Bradshaw, R.L., and W.C. McClain, eds. 1971. Project Salt Vault: A Demonstration of the Disposal of High-Activity Solidified Wastes in Underground Salt Mines. ORNL-4555. Oak Ridge, TN: Oak Ridge National Laboratory. (Copy on file in the SWCF as WPO\#48808.)

T11 McClain, W.C., and R.L. Bradshaw. 1970. "Status of Investigations of Salt Formations for Disposal of Highly Radioactive Power-Reactor Wastes," Nuclear Safety. Vol. 11, no. 2, 130 141.

T12 Teller, E. 1959. "The Plowshare Program," Proceedings of the Second Plowshare Symposium, San Francisco, CA, May 13-15, 1959. UCRL-5675. Livermore, CA: Livermore Radiation Laboratory. 8-13. (Copy on file in the SWCF as WPO\#44080.)

T13 Wheeler, B.R., B.R. Dickey, G.E. Lohse, D.E. Black, D.W. Rhodes, and J.A. Buckham. 1967. "Storage of Radioactive Solids in Underground Facilities: Current ICPP Practices and Future Concepts," Disposal of Radioactive Wastes into the Ground, Proceedings of a Symposium Jointly Organized by the International Atomic Energy Agency and the European Nuclear Energy Agency of the OECD, Vienna, Austria, May 29-June 2, 1967. Vienna: International Atomic Energy Agency. 421-440. (Copy on file in the SWCF as WPO\#48156.)

T14 Boffey, P.M. 1975. "Radioactive Waste Disposal: The Atomic Energy Commission Brings the Academy to Heel," The Brain Bank of America: An Inquiry into the Politics of Science. P.M. Boffey. New York, NY: McGraw-Hill Book Company. 89-111, 276278.

T15 Carter, L.J. 1987. Nuclear Imperatives and Public Trust: Dealing with Radioactive Waste. Washington, DC: Resources for the Future, Inc.; [Baltimore, MD]: Distributed by Johns Hopkins University Press. 64-69, 86, 177.

T16 U.S. Congress. 1970. "Radioactive Waste Management: An Interim Report of the Committee on Radioactive Waste Management," Congressional Record. Vol. 116, pt. 10, 13592-13593.

T17 Davies, L.E. 1969. "Fire Cleanup Keeps Plutonium Plant Busy," New York Times. June 27,1969, p. 10. 
T18 Perge, A. 1982. "Historical Overview," Proceedings of Alpha-Contaminated Waste Management Workshop, Gaithersburg, MD, August 10-13, 1982. CONF-820845. Oak Ridge, TN: Oak Ridge National Laboratory. 17-30.

T19 NAS/NRC (National Academy of Sciences/National Research Council). 1970. Disposal of Solid Radioactive Wastes in Bedded Salt Deposits. Washington, DC: Committee on Radioactive Waste Management, National Academy of Sciences/National Research Council; U.S. Government Printing Office. (Copy on file in the SWCF as WPO\#43139.)

T20 Cooper, J.B., and J.M. Glanzman. 1971. Geohydrology of Project Gnome Site, Eddy County, New Mexico. Geological Survey Professional Paper 712-A. Washington, DC: United States Government Printing Office.

T21 Brokaw, A.L., C.L. Jones, M.E. Cooley, and W.H. Hays. 1972 . Geology and Hydrology of the Carlsbad Potash Area, Eddy and Lea Counties, New Mexico. Open-file report USGS4339-1. Denver, CO: United States Department of the Interior, Geological Survey. (Copy on file in the SWCF as WPO\#43356.)

T22 Anderson, R.E., D.H. Eargle, and B.O. Davis. 1973. Geologic and Hydrologic Summary of Salt Domes in Gulf Coast Region of Texas, Louisiana, Mississippi, and Alabama. Open-file report USGS-4339-2. Denver, CO: United States Department of the Interior, Geological Survey. (Copy on file in the SWCF as WPO\#43862.)

T23 Mytton, J.W. 1973. Two Salt Structures in Arizona: The Supai Salt Basin and the Luke Salt Body. Open-file report USGS-4339-3. Denver, CO: United States Department of the Interior, Geological Survey. (Copy on file in the SWCF as WPO\#48691.)

T24 Bachman, G.O., R.B. Johnson, and F.A. Swenson. 1973. Stability of Salt in the Permian Salt Basin of Kansas, Oklahoma, Texas, and New Mexico, With a Section on Dissolved Salts in Surface Water. Open-file report USGS-4339-4. Denver, CO: United States Department of the Interior, Geological Survey. (Copy on file in the SWCF as WPO\#41298.)

T25 Merewether, E.A., J.A. Sharps, J.R. Gill, and M.E. Cooley. 1973. Shale, Mudstone, and Claystone as Potential Host Rocks for Underground Emplacement of Waste. Open-file report USGS-4339-5. Denver, CO: United
States Department of the Interior, Geological Survey. (Copy on file in the SWCF as WPO\#48204.)

T26 Hite, R.J., and S.W. Lohman. 1973. Geologic Appraisal of Paradox Basin Salt Deposits for Waste Emplacement. Open-file report USGS4339-6. Denver, CO: United States Department of the Interior, Geological Survey. (Copy on file in the SWCF as WPO\#48650.)

T27 Jones, C.L., M.E. Cooley, and G.O. Bachman. 1973. Salt Deposits of Los Medaños Area, Eddy and Lea Counties, New Mexico, With Sections on Ground Water Hydrology. Openfile report USGS-4339-7. Denver, CO: United States Department of the Interior, Geological Survey. (Copy on file in the SWCF as WPO\#43835.)

T28 Bachman, G.O. 1973. Surficial Features and Late Cenozoic History in Southeastern New Mexico. Open-file report USGS-4339-8. Denver, CO: United States Department of the Interior, Geological Survey. (Copy on file in the SWCF as WPO\#41293.)

T29 Barnes, H. 1974. "Geologic and Hydrologic Background for Selecting Site of Pilot-plant Repository for Radioactive Waste," Bulletin of the Association of Engineering Geologists. Vol. XI, no. 1, 83-92.

T30 NAS/NRC (National Academy of Sciences/National Research Council). 1984. Review of the Scientific and Technical Criteria for the Waste Isolation Pilot Plant (WIPP). Panel on the Waste Isolation Pilot Plant, Board on Radioactive Waste Management, Commission on Physical Sciences, Mathematics, and Resources, National Research Council. DOE/DP/48015-1. Washington, DC: National Academy Press.

T31 Rechard, R.P., ed. 1992. User's Reference Manual for CAMCON: Compliance Assessment Methodology Controller, Version 3.0. SAND90-1983. Albuquerque, NM: Sandia National Laboratories.

T32 Rasmussen, N.C. 1975. Reactor Safety Study: An Assessment of Accident Risks in U.S. Commercial Nuclear Power Plants. NUREG75/014, WASH-1400. Washington, DC: U.S. Nuclear Regulatory Commission. (Available from the NTIS as PB-248 200-Set.)

T33 Sandia National Laboratories and U.S. Geological Survey. 1983. Basic Data Report for Drillhole ERDA 6 (Waste Isolation Pilot Plant - WIPP). SAND79-0267. Albuquerque, NM: Sandia National Laboratories. 
T34 Powers, D.W., S.J. Lambert, S-E. Shaffer, L.R. Hill, and W.D. Weart, eds. 1978. Geological Characterization Report, Waste Isolation Pilot Plant (WIPP) Site, Southeastern New Mexico. SAND78-1596. Albuquerque, NM: Sandia [National] Laboratories. Vols. I-II.

T35 Gulick, C.W., Jr. 1978. Borehole PluggingMaterials Development Program. SAND780715. Albuquerque, NM: Sandia National Laboratories.

T36 Barr, G.E., and P.D. O'Brien. 1976. "Selective Adsorption of Radionuclides in Geologic Storage Media; Disclosure of Potentially Patentable Subject." Unpublished Memorandum from G.C. Newlin to W.D. Weart, March 11, 1976. Albuquerque, NM: Sandia National Laboratories. (Copy on file in the SWCF as ERMS\#500136.)

T37 Dawson, P.R., and J.R. Tillerson. 1978. Nuclear Waste Canister Thermally Induced Motion. SAND78-0566. Albuquerque, NM: Sandia National Laboratories.

T38 Molecke, M.A. 1978. Waste Isolation Pilot Plant Transuranic Wastes Experimental Characterization Program: Executive Summary. SAND78-1356. Albuquerque, NM: Sandia [National] Laboratories.

T39 Sandia [National] Laboratories. 1979. Summary of Research and Development Activities in Support of Waste Acceptance Criteria for WIPP. Comp. T.O. Hunter, SAND79-1305. Albuquerque, NM: Sandia [National] Laboratories.

T40 Sandia [National] Laboratories. 1977. Waste Isolation Pilot Plant (WIPP) Conceptual Design Report. SAND77-0274. Albuquerque, NM: Sandia [National] Laboratories.

T41 Gulick, C.W., Jr. 1979. Borehole Plugging Program, Plugging of ERDA No. 10 Drill Hole. SAND79-0789. Albuquerque, NM: Sandia National Laboratories.

T42 Tyler, L.D., R.V. Matalucci, M.A. Molecke, D.E. Munson, E.J. Nowak, and J.C. Stormont. 1988. Summary Report for the WIPP Technology Development Program for Isolation of Radioactive Waste. SAND88-0844. Albuquerque, NM: Sandia National Laboratories.

T43 Smith, T. 1982. "Risk and Safety Analyses for Disposal of Alpha-Contaminated Waste in INEL," Proceedings of Alpha-Contaminated Waste Management Workshop, Gaithersburg, MD, August 10-13, 1982. CONF-820845. Oak
Ridge, TN: Oak Ridge National Laboratory. 395-436.

T44 Lamoreaux, G.H., L.E. Romesberg, S.H. Sutherland, and T.A. Duffey. 1980. "ContactHandled Transuranic Transportation System Structural Analysis (TRUPACT)," Patram 80, 6th International Symposium on Packaging and Transporting Radioactive Materials, Berlin, Germany, November 10-14, 1980. Ed. H.W. Hübner. Berlin: Bundesanst für Materialprüf (BAM). Vol. 2, 1214-1221

T45 May, R.A., L.E. Romesberg, H.R. Yoshimura, W.E. Baker, and J.C. Hokanson. 1980. "Analytical and Empirical Evaluation of LowLevel Waste Drum Response to Accident Environments," Patram 80, 6th International Symposium on Packaging and Transporting Radioactive Materials, Berlin, Germany, November 10-14, 1980. Ed. H.W. Hübner. Berlin: Bundesanst für Materialprüf (BAM). Vol. 2, 1321-1328.

T46 Romesberg, L.E., S.H. Sutherland, G.H. Lamoreaux, and R.G. Eakes. 1981. "Design of Packaging for Transporting Transuranic Contaminated Wastes," Damage Prevention in the Transportation Environment, Proceedings of the 34th Meeting of the Mechanical Failures Prevention Group, National Bureau of Standards, Gaithersburg, MD, October 21-23, 1981. Ed. T.R. Shives. NBS Special Publication 652; SAND81-1308C. Washington, DC: U.S. Department of Commerce, National Bureau of Standards; Albuquerque, NM: Sandia National Laboratories. $16 \mathrm{pp}$.

T47 Kosiewicz, S.T., B.L. Barraclough, and A. Zerwekh. 1980. Studies of Transuranic Waste Storage Under Conditions Expected in the Waste Isolation Pilot Plant (WIPP), Interim Summary Report, October 1, 1977-June 15, 1979. LA-7931-PR. Los Alamos, NM: Los Alamos Scientific Laboratory. (Copy on file in the SWCF as WPO\#48813.)

T48 Lappin, A.R., R.L. Hunter, D.P. Garber, and P.B. Davies, eds. 1989. Systems Analysis, Long-Term Radionuclide Transport, and Dose Assessments, Waste Isolation Pilot Plant (WIPP), Southeastem New Mexico; March 1989. SAND89-0462. Albuquerque, NM: Sandia National Laboratories.

T49 DOE (U.S. Department of Energy). 1979. Draft Environmental Impact Statement, Waste Isolation Pilot Plant. DOE/EIS-0026-D. Washington, DC: U.S. Department of Energy. Vols. 1-2. 
T50 Campbell, J.E., R.T. Dillon, M.S. Tierney, H.T. Davis, P.E. McGrath, F.J. Pearson, Jr., H.R. Shaw, J.C. Helton, and F.A. Donath. 1978. Risk Methodology for Geologic Disposal of Radioactive Waste: Interim Report. SAND780029, NUREG/CR-0458. Albuquerque, NM: Sandia National Laboratories.

T51 Cranwell, R.M., J.E. Campbell, J.C. Helton, R.L. Iman, D.E. Longsine, N.R. Ortiz, G.E. Runkle, and M.J. Shortencarier. 1987. Risk Methodology for Geologic Disposal of Radioactive Waste: Final Report. SAND812573, NUREG/CR-2452. Albuquerque, NM: Sandia National Laboratories.

T52 Hunter, T.O. 1979. "Technical Issues of Nuclear Waste Isolation in the Waste Isolation Pilot Plant (WIPP)," Proceedings, 87th National Meeting of American Institute of Chemical Engineers, Boston, MA, August 1922, 1979. SAND79-1117C. New York, NY: American Institute of Chemical Engineers. (Copy on file in the SWCF as WPO\#26711.)

T53 Sattler, A.R., and C.L. Christensen. 1980. Measurements of Very Large Deformations in "Potash Salt" in Conjunction With an Ongoing Mining Operation. SAND79-2254. Albuquerque, NM: Sandia National Laboratories.

T54 McVey, D.F. 1981. Analysis of Data from Line Source Thermal Conductivity Measurements Taken In Situ in Dome Salt at the Avery Island Mine. SAND81-1232. Albuquerque, NM: Sandia National Laboratories.

T55 Ewing, R.I. 1981. WIPP Test of a Radiant Heater in the Avery Island Salt Mine. SAND811305. Albuquerque, NM: Sandia National Laboratories.

T56 Christensen, C.L., R.D. Statler, and E.W. Peterson. 1980. Downhole Television (DHTV) Applications in Borehole Plugging. SAND800459. Albuquerque, NM: Sandia National Laboratories.

T57 Bingham, F.W., and G.E. Barr. 1980 "Development of Scenarios for the Long-Term Release of Radionuclides from the Proposed Waste Isolation Pilot Plant in Southeastern New Mexico," Scientific Basis for Nuclear Waste Management, Proceedings of the International Symposium, Boston, MA, November 27-30, 1979. Ed. C.J.M. Northrup, Jr. SAND790955C. New York, NY: Plenum Press. Vol. 2, $771-778$.

T58 Bartlett, J.W., H.C. Burkholder, and W.K. Winegardner. 1977. "Safety Assessment of
Geologic Repositories for Nuclear Waste," Nuclear Systems Reliability Engineering and Risk Assessment. Eds. J.B. Fussell and G.R. Burdick. Philadelphia, PA: Society for Industrial and Applied Mathematics. 636-660. (Copy on file in SWCF as WPO\#45677.)

T59 DOE (U.S. Department of Energy). 1980. WIPP SAR: Waste Isolation Pilot Plant Safety Analysis Report. Washington, DC: U.S. Department of Energy. Vols. 1-5.

T60 Molecke, M.A., and T.M. Torres. 1984. "The Waste Package Materials Field Test in S.E. New Mexico Salt," Scientific Basis for Nuclear Waste Management VII, Materials Research Society Symposia Proceedings, Boston, MA, November 14-17, 1983. Ed. G.L. McVay. SAND83-1516C. New York, NY: NorthHolland. Vol. 26, 69-76.

T61 Bechtel National, Inc. 1986. WIPP Design Validation Final Report. DOE/WIPP-86-010. San Francisco, CA: Bechtel National, Inc.

T62 DOE (U.S. Department of Energy). 1997. Waste Isolation Pilot Plant Disposal Phase Final Supplemental Environmental Impact Statement. September 1997. DOE/EIS-0026-S2. Carlsbad, NM: Department of Energy, Carlsbad Area Office.

T63 State of New Mexico, ex rel., Jeff Bingaman, Attorney General of the State of New Mexico, Plaintiff, v. The United States Department of Energy, et al., Defendants. 1981. "Stipulated Agreement." Civil Action No. 81-0363 JB. United States District Court for the District of New Mexico, July 1, 1981. (Copy on file in the SWCF as WPO\#42008.)

T64 Popielak, R.S., R.L. Beauheim, S.R. Black, W.E. Coons, C.T. Ellingson, and R.L. Olsen. 1983. Brine Reservoirs in the Castile Formation, Waste Isolation Pilot Plant (WIPP) Project, Southeastern New Mexico. TME 3153. Albuquerque, NM: U.S. Department of Energy, Waste Isolation Pilot Plant. (Copy on file in the SWCF as WPO\#42085.)

T65 Campbell, J.E., and R.M. Cranwell. 1988. "Performance Assessment of Radioactive Waste Repositories," Science. Vol. 239, no. 4846, 1389-1392.

T66 Campbell, J.E., C.D. Leigh, and D.E. Longsine. 1991. NEFTRAN-S: A Network Flow and Contaminant Transport Model for Statistical and Deterministic Simulations Using Personal Computers. SAND90-1987. Albuquerque, NM: Sandia National Laboratories. 
T67 IAEA (International Atomic Energy Agency). 1981. Safety Assessment for the Underground Disposal of Radioactive Wastes. Safety Series No. 56. Vienna, Austria: International Atomic Energy Agency.

T68 Matalucci, R.V., C.L. Christensen, T.O. Hunter, M.A. Molecke, and D.E. Munson. 1982. Waste Isolation Pilot Plant (WIPP) Research and Development Program: In Situ Testing Plan, March 1982. SAND81-2628. Albuquerque, NM: Sandia National Laboratories.

T69 Lambert, S.J. 1983. Dissolution of Evaporites In and Around the Delaware Basin, Southeastern New Mexico and West Texas. SAND82-0461. Albuquerque, NM: Sandia National Laboratories.

T70 Snyder, R.P., L.M. Gard, Jr., and J.W. Mercer. 1982. Evaluation of Breccia Pipes in Southeastern New Mexico and Their Relation to the Waste Isolation Pilot Plant (WIPP) Site, with a Section on Drill-Stem Tests, WIPP 31. Open-File Report 82-968. Denver, CO: Prepared by the U.S. Geological Survey for the Albuquerque Operations Office, U.S. Department of Energy.

T71 Mercer, J.W. 1983. Geohydrology of the Proposed Waste Isolation Pilot Plant Site, Los Medaños Area, Southeastern New Mexico. Open-File Report 83-4016. Albuquerque, NM: U.S. Geological Survey.

T72 Gonzalez, D.D. 1983. Groundwater Flow in the Rustler Formation, Waste Isolation Pilot Plant (WIPP), Southeast New Mexico (SENM): Interim Report. SAND82-1012. Albuquerque, NM: Sandia National Laboratories.

T73 Borns, D.J., L.J. Barrows, D.W. Powers, and R.P. Snyder. 1983. Deformation of Evaporites Near the Waste Isolation Pilot Plant (WIPP) Site. SAND82-1069. Albuquerque, NM: Sandia National Laboratories.

T74 Earth Technology Corporation. 1988. Final Report for Time Domain Electromagnetic (TDEM) Surveys at the WIPP Site. H. Cline and M. Blohm. SAND87-7144. Albuquerque, NM: Sandia National Laboratories.

T75 Beauheim, R.L., B.W. Hassinger, and J.A. Klaiber. 1983. Basic Data Report for Borehole Cabin Baby-1 Deepening and Hydrologic Testing, Waste Isolation Pilot Plant (WIPP) Project, Southeastern New Mexico. WTSDTME-020. Albuquerque, NM: U.S. Department of Energy, Waste Isolation Pilot Plant.
T76 Lappin, A.R. 1988. Summary of SiteCharacterization Studies Conducted From 1983 Through 1987 at the Waste Isolation Pilot Plant (WIPP) Site, Southeastern New Mexico. SAND88-0157. Albuquerque, NM: Sandia National Laboratories.

T77 Lynch, R.W., R.L. Hunter, D.R. Anderson, F.W. Bingham, J.M. Covan, G.F. Hohnstrieter, T.O. Hunter, R.D. Klett, E.E. Ryder, T.L. Sanders, and W.D. Weart. 1991. Deep Geologic Disposal in the United States: The Waste Isolation Pilot Plant and Yucca Mountain Projects. SAND90-1656. Albuquerque, NM: Sandia National Laboratories.

T78 Nowak, E.J. 1986. "Brine Migration Studies in the Waste Isolation Pilot Plant (WIPP)," Waste Management '86 - Waste Isolation in the U.S., Technical Programs and Public Education, Proceedings of the Symposium on Waste Management, Tucson, AZ, March 2-6, 1986. Ed. R.G. Post. SAND85-1987C. Tucson, AZ: University of Arizona. Vol. 2, 153-158.

T79 Beauheim, R.L. $1986 . \quad$ Hydraulic-Test Interpretations for Well DOE-2 at the Waste Isolation Pilot Plant (WIPP) Site. SAND861364. Albuquerque, NM: Sandia National Laboratories.

T80 NRC (Nuclear Regulatory Commission). 1994. "Part 71-Packaging and Transportation of Radioactive Material," Code of Federal Regulations 10, Part 71. Washington, DC: Superintendent of Documents, U.S. Government Printing Office.

T81 Morgan, H.S., C.M. Stone, and R.D. Krieg. 1985. "The Use of Field Data to Evaluate and Improve Drift Response Models for the Waste Isolation Pilot Plant (WIPP)," Research and Engineering Applications in Rock Masses, Proceedings of the 26th U.S. Symposium on Rock Mechanics, Rapid City, SD, June 26-28, 1985. Ed. E. Ashworth. Boston, MA: A.A. Balkema. Vol. 2, 769-776.

T82 Morgan, H.S., C.M. Stone, and R.D. Krieg. 1986. An Evaluation of WIPP Structural Modeling Capabilities Based on Comparisons with South Drift Data. SAND85-0323. Albuquerque, NM: Sandia National Laboratories.

T83 Romesberg, L.E., and M.L. Hudson. 1986. "Impact, Puncture and Thermal Testing of TRUPACT-I," Proceedings of an International Symposium on the Packaging and Transportation of Radioactive Materials 
(PATRAM 86), Davos, Switzerland, June 1620, 1986. SAND84-2067C, IAEA-SM-286/107. Vienna, Austria: International Atomic Energy Agency. Vol. 2, 511-519.

T84 Romesberg, L.E., R.S. Longenbaugh, and B.J. Joseph. 1989. Fire Testing and Analysis of TRUPACT-I Thermal Test Article. SAND862710, TTC-0704. Albuquerque, NM: Sandia National Laboratories.

T85 Sandoval, R.P., and L.C. Sanchez. 1987. "TRUPACT Containment Issues," Proceedings of an International Symposium on the Packaging and Transportation of Radioactive Materials (PATRAM '86), Davos, Switzerland, June 16-20, 1986. SAND85-2203C. Vienna, Austria: International Atomic Energy Agency. Vol. 2, 719-727.

T86 Warrant, M.M., J.M. Nelsen, and S.W. Woolfolk. 1987. "Containment Analysis of TRUPACT-I," Proceedings of an International Symposium on the Packaging and Transportation of Radioactive Materials (PATRAM '86), Davos, Switzerland, June 1620, 1986. SAND85-2188C, IAEA-SM-286111P. Vienna, Austria: International Atomic Energy Agency. Vol. 2, 529-536.

T87 Beauheim, R.L. 1987. Analysis of Pumping Tests of the Culebra Dolomite Conducted at the H-3 Hydropad at the Waste Isolation Pilot Plant (WIPP) Site. SAND86-2311. Albuquerque, NM: Sandia National Laboratories.

T88 Haug, A., V.A. Kelley, A.M. LaVenue, and J.F. Pickens. 1987. Modeling of Ground-Water Flow in the Culebra Dolomite at the Waste Isolation Pilot Plant (WIPP) Site: Interim Report. SAND86-7167. Albuquerque, NM: Sandia National Laboratories.

T89 Reeves, M., V.A. Kelley, and J.F. Pickens. 1987. Regional Double-Porosity Solute Transport in the Culebra Dolomite: An Analysis of Parameter Sensitivity and Importance at the Waste Isolation Pilot Plant (WIPP) Site. SAND87-7105. Albuquerque, NM: Sandia National Laboratories.

T90 Nowak, E.J., D.F. McTigue, and R. Beraún. 1988. Brine Inflow to WIPP Disposal Rooms: Data, Modeling, and Assessment. SAND880112. Albuquerque, NM: Sandia National Laboratories.

T91 Rechard, R.P. 1991. "CAMCON: Computer System for Assessing Regulatory Compliance of the Waste Isolation Pilot Plant," Proceedings of the International Conference on Probabilistic
Safety Assessment and Management (PSAM), Beverly Hills, CA, February 4-7, 1991. Ed. G. Apostolakis. SAND90-2094C. New York, NY: Elsevier Science Publishers. Vol. 2, 899904.

T92 Rechard, R.P. 1989. Review and Discussion of Code Linkage and Data Flow in Nuclear Waste Compliance Assessments. SAND87-2833. Albuquerque, NM: Sandia National Laboratories.

T93 Beauheim, R.L. 1989. Interpretation of the $H$ $11 b 4$ Hydraulic Tests and the H-II Multipad Pumping Test of the Culebra Dolomite at the Waste Isolation Pilot Plant (WIPP) Site. SAND89-0536. Albuquerque, NM: Sandia National Laboratories.

T94 LaVenue, A.M., A. Haug, and V.A. Kelley. 1988. Numerical Simulation of Ground-Water Flow in the Culebra Dolomite at the Waste Isolation Pilot Plant (WIPP) Site: Second Interim Report. SAND88-7002. Albuquerque, NM: Sandia National Laboratories.

T95 LaVenue, A.M., T.L. Cauffman, and J.F. Pickens. 1990. Ground-Water Modeling of the Culebra Dolomite. Volume I: Model Calibration. SAND89-7068/1. Albuquerque, NM: Sandia National Laboratories.

T96 Beauheim, R.L., T.F. Dale, and J.F. Pickens. 1991. Interpretations of Single-Well Hydraulic Tests of the Rustler Formation Conducted in the Vicinity of the Waste Isolation Pilot Plant Site, 1988-1989. SAND89-0869. Albuquerque, NM: Sandia National Laboratories.

T97 Nuclear Packaging, Inc. 1989. Safety Analysis Report for the TRUPACT-II Shipping Package, Rev. 4. SR00045. Washington, DC: Nuclear Packaging, Inc. Vols. 1-5. (Copy on file in the U.S. Nuclear Regulatory Commission Public Document Room, Washington, DC, 1-800-3974209.)

T98 Jensen, A.L., C.L. Howard, R.L. Jones, and T.P. Peterson. 1993. Room Q Data Report: Test Borehole Data From April 1989 Through November 1991. SAND92-1172. Albuquerque, NM: Sandia National Laboratories.

T99 Munson, D.E., A.F. Fossum, and P.E. Senseny. 1989. Advances in Resolution of Discrepancies Between Predicted and Measured In Situ WIPP Room Closures. SAND88-2948. Albuquerque, NM: Sandia National Laboratories.

T100 DOE (U.S. Department of Energy). 1989. "Waste Isolation Pilot Plant; Availability of 
Draft Supplement to the Final Environmental Impact Statement," Federal Register. Vol. 54, no. $76,16350-16352$.

T101 DOE (U.S. Department of Energy). 1989. Waste Isolation Pilot Plant No-Migration Variance Petition. DOE/WIPP 89-003, Rev. 0. Carlsbad, NM: Westinghouse Electric Corporation, Waste Isolation Division.

T102 Brush, L.H. 1990. Test Plan for Laboratory and Modeling Studies of Repository and Radionuclide Chemistry for the Waste Isolation Pilot Plant. SAND90-0266. Albuquerque, NM: Sandia National Laboratories.

T103 Brush, L.H., D. Grbic-Galic, D.T. Reed, X. Tong, R.H. Vreeland, and R.E. Westerman. 1991. "Preliminary Results of Laboratory Studies of Repository Chemistry for the Waste Isolation Pilot Plant," Scientific Basis for Nuclear Waste Management XIV, Materials Research Society Symposium Proceedings, Boston, MA, November 26-29, 1990. Eds. T.A. Abrajano, Jr. and L.H. Johnson. SAND901031C. Pittsburgh, PA: Materials Research Society. Vol. 212, 893-900.

T104 Brush, L.H., M.A. Molecke, A.R. Lappin, R.E. Westerman, X. Tong, J.N.P. Black, D. GrbicGalic, R.E. Vreeland, and D.T. Reed. 1991. "Laboratory and Bin-Scale Tests of Gas Generation for the Waste Isolation Pilot Plant," Waste-Generated Gas at the Waste Isolation Pilot Plant, Papers Presented at the Nuclear Energy Agency Workshop on Gas Generation and Release from Radioactive Waste Repositories. Eds. P.B. Davies, L.H. Brush, M.A. Molecke, F.T. Mendenhall, and S.W. Webb. SAND91-2378. Albuquerque, NM: Sandia National Laboratories. 2-1 through 213.

T105 Reed, D.T., S. Okajima, L.H. Brush, and M.A. Molecke. 1993. "Radiolytically-Induced Gas Production in Plutonium-Spiked WIPP Brine," Scientific Basis for Nuclear Waste Management XVI, Materials Research Society Symposium Proceedings, Boston, MA, November 30 December 4, 1992. Eds. C.G. Interrante and R.T. Pabalan. SAND92-7283C. Pittsburgh, PA: Materials Research Society. Vol. 294, 431438.

T106 Telander, M.R., and R.E. Westerman. 1993. Hydrogen Generation by Metal Corrosion in Simulated Waste Isolation Pilot Plant Environments: Progress Report for the Period November 1989 through December 1992. SAND92-7347. Albuquerque, NM: Sandia National Laboratories.
T107 Francis, A.J., and J.B. Gillow. 1994. Effects of Microbial Processes on Gas Generation Under Expected Waste Isolation Pilot Plant Repository Conditions, Progress Report Through 1992. SAND93-7036. Albuquerque, NM: Sandia National Laboratories.

T108 DOE (U.S. Department of Energy). 1989. Draft Supplement, Environmental Impact Statement, Waste Isolation Pilot Plant. DOE/EIS-0026-DS. Washington, DC: U.S. Department of Energy, Assistant Secretary for Defense Programs. Vols. 1-2. (Copy on file in the SWCF as WPO\#43133.)

T109 Hunter, R.L. 1989. Events and Processes for Constructing Scenarios for the Release of Transuranic Waste from the Waste Isolation Pilot Plant, Southeastern New Mexico. SAND89-2546. Albuquerque, NM: Sandia National Laboratories.

T110 Marietta, M.G., S.G. Bertram-Howery, D.R Anderson, K.F. Brinster, R.V. Guzowski, H. Iuzzolino, and R.P. Rechard. 1989. Performance Assessment Methodology Demonstration: Methodology Development for Evaluating Compliance With EPA 40 CFR 191, Subpart B, for the Waste Isolation Pilot Plant. SAND89-2027. Albuquerque, NM: Sandia National Laboratories.

T111 Bertram-Howery, S.G., M.G. Marietta, D.R. Anderson, K.F. Brinster, L.S. Gomez, R.V. Guzowski, and R.P. Rechard. 1989. Draft Forecast of the Final Report for the Comparison to 40 CFR Part 191, Subpart B, for the Waste Isolation Pilot Plant. SAND881452. Albuquerque, NM: Sandia National Laboratories.

T112 DOE (U.S. Department of Energy). 1990. WIPP Test Phase Plan: Performance Assessment. DOE/WIPP 89-011, Revision 0. Carlsbad, NM: United States Department of Energy, Waste Isolation Pilot Plant.

T113 DOE (U.S. Department of Energy). 1990. Final Safety Analysis Report, Waste Isolation Pilot Plant, Carlsbad, New Mexico. WP 02-9, Rev. 0. Carlsbad, NM: Westinghouse Electric Corporation. Vols. 1-8. (Copy on file in the SWCF as WPO\#43327.)

T114 Guzowski, R.V. $1990 . \quad$ Preliminary Identification of Scenarios That May Affect the Escape and Transport of Radionuclides From the Waste Isolation Pilot Plant, Southeastern New Mexico. SAND89-7149. Albuquerque, NM: Sandia National Laboratories. 
T115 Rechard, R.P., H.J. Iuzzolino, J.S. Rath, A.P. Gilkey, R.D. McCurley, and D.K. Rudeen. 1989. User's Manual for CAMCON: Compliance Assessment Methodology Controller. SAND88-1496. Albuquerque, NM: Sandia National Laboratories.

T116 Bertram-Howery, S.G., M.G. Marietta, R.P. Rechard, P.N. Swift, D.R. Anderson, B.L. Baker, J.E. Bean, Jr., W. Beyeler, K.F. Brinster, R.V. Guzowski, J.C. Helton, R.D. McCurley, D.K. Rudeen, J.D. Schreiber, and P. Vaughn. 1990. Preliminary Comparison with 40 CFR Part 191, Subpart B for the Waste Isolation Pilot Plant, December 1990. SAND90-2347. Albuquerque, NM: Sandia National Laboratories.

T117 Rechard, R.P., W. Beyeler, R.D. McCurley, D.K. Rudeen, J.E. Bean, and J.D. Schreiber. 1990. Parameter Sensitivity Studies of Selected Components of the Waste Isolation Pilot Plant Repository/Shaft System. SAND89-2030. Albuquerque, NM: Sandia National Laboratories.

T118 DOE (U.S. Department of Energy). 1992. Resource Conservation and Recovery Act Part $B$ Permit Application. DOE/WIPP 91-005, Revision 1.0. Carlsbad, NM: Waste Isolation Pilot Plant. Vols. I-VII.

T119 DOE (U.S. Department of Energy). 1991. Report of the Geotechnical Panel on the Effective Life of Rooms in Panel 1. DOE/WIPP 91-023. Carlsbad, NM: Westinghouse Electrical Corporation, Waste Isolation Division.

T120 DOE (U.S. Department of Energy). 1992. WIPP Supplementary Roof Support System Room 1, Panel I Geotechnical Field Data Analysis Bi-Annual Report. DOE/WIPP 92024. Carlsbad, NM: Westinghouse Electrical Corporation, Waste Isolation Division.

T121 WIPP PA (Performance Assessment) Division. 1991-1992. Preliminary Comparison with 40 CFR Part 191, Subpart B for the Waste Isolation Pilot Plant, December 1991. SAND91-0893/1/2/3. Albuquerque, NM: Sandia National Laboratories. Vols. 1-3.

T122 DOE (U.S. Department of Energy). 1993. Test Phase Plan for the Waste Isolation Pilot Plant. DOE/WIPP 89-011, Revision 1. Albuquerque, NM: U.S. Department of Energy, WIPP Project Integration Office.

T123 DOE (U.S. Department of Energy). 1993. Waste Retrieval Plan for the Waste Isolation
Pilot Plant. DOE/WIPP-89-022, Revision 1. Washington, DC: U.S. Department of Energy.

T124 NRC (National Research Council). 1992. A Letter Report by the Panel on the Waste Isolation Pilot Plant, Board on Radioactive Waste Management. Washington, DC: Commission on Geosciences, Environment, and Resources, National Research Council. (Copy on file in the SWCF as WPO\#35203-35204.)

T125 WIPP PA (Performance Assessment) Department. 1992-1993. Preliminary Performance Assessment for the Waste Isolation Pilot Plant, December 1992. SAND920700/1/2/3/4/5. Albuquerque, NM: Sandia National Laboratories. Vols. 1-5.

T126 Francis, A.J., J.B. Gillow, and M.R. Giles. 1997. Microbial Gas Generation Under Expected Waste Isolation Pilot Plant Repository Conditions. SAND96-2582. Albuquerque, NM: Sandia National Laboratories.

T127 Telander, M.R., and R.E. Westerman. 1997. Hydrogen Generation by Metal Corrosion in Simulated Waste Isolation Pilot Plant Environments. SAND96-2538. Albuquerque, NM: Sandia National Laboratories.

T128 DOE (U.S. Department of Energy). 1995. Engineered Alternatives Cost/Benefit Study Final Report. DOE/WIPP 95-2135 Revision 0. Albuquerque, NM: IT Corporation; Carlsbad, NM: United States Department of Energy, Waste Isolation Pilot Plant, Carlsbad Area Office.

T129 DOE (U.S. Department of Energy). 1995. Transuranic Waste Baseline Inventory Report (Revision 2). DOE/CAO-95-1121. Carlsbad, NM: U.S. Department of Energy, Carlsbad Area Office.

T130 Prindle, N.H., F.T. Mendenhall, D.M. Boak, W. Beyeler, D. Rudeen, R.C. Lincoln, K. Trauth, D.R. Anderson, M.G. Marietta, and J.C. Helton. 1996. The Second Iteration of the Systems Prioritization Method: A Systems Prioritization and Decision-Aiding Tool for the Waste Isolation Pilot Plant, Volume 1: Synopsis of Method and Results. SAND95-2017/1. Albuquerque, NM: Sandia National Laboratories.

T131 Meigs, L.C., and J.T. McCord. 1996. "Physical Transport in the Culebra Dolomite." Unpublished Memorandum to File, July 11, 1996. Albuquerque, NM: Sandia National Laboratories. (Copy on file in the SWCF as WPO\#39167.) 
T132 Meigs, L.C., R.L. Beauheim, J.T. McCord, Y.W. Tsang, and R. Haggerty. 1997. "Design, Modelling, and Current Interpretations of the H19 and H-11 Tracer Tests at the WIPP Site," Field Tracer Experiments, Role in the Prediction of Radionuclide Migration: Synthesis and Proceeding of an NEAVEC GEOTRAP Workshop, Cologne, Germany, August 28-30, 1996. SAND96-2796C. Paris: Nuclear Energy Agency, Organisation for Economic Co-Operation and Development. 157-169.

T133 Papenguth, H.W., and Y.K. Behl. 1996. "Test Plan: Evaluation of Dissolved Actinide Retardation at the Waste Isolation Pilot Plant." TP 96-02. Albuquerque, NM: Sandia National Laboratories. (Copy on file in the SWCF as WPO\#31336.)

T134 Brush, L.H., and L.J. Storz. 1996. "Revised Ranges and Probability Distributions of $\mathrm{K}_{d} \mathrm{~s}$ for Dissolved $\mathrm{Pu}, \mathrm{Am}, \mathrm{U}, \mathrm{Th}$, and $\mathrm{Np}$ in the Culebra for the PA Calculations to Support the WIPP CCA." Memo to M.S. Tierney, July 24, 1996. Albuquerque, NM: Sandia National Laboratories. (Copy on file in the SWCF as WPO\#41561.)

T135 EPA (U.S. Environmental Protection Agency). 1996. "40 CFR Part 194: Decision to Certify Whether the Waste Isolation Pilot Plant Complies with the 40 CFR Part 191 Disposal Regulations and the 40 CFR Part 194 Compliance Criteria; Advance Notice of Proposed Rulemaking (ANPR)," Federal Register. Vol. 61, no. 222, 58499-58500.

T136 Taugher, M. 1996. "Key WIPP Document Exceeds 400 Lbs," Albuquerque Journal. November 21, 1996. Section D, page 3.

T137 NAS/NRC (National Academy of Sciences/ National Research Council). 1996. The Waste Isolation Pilot Plant: A Potential Solution for the Disposal of Transuranic Waste. Committee on the Waste Isolation Pilot Plant, Board on
Radioactive Waste Management, Commission on Geosciences, Environment, and Resources, National Research Council. Washington, DC: National Academy Press. 6, 79-80.

T138 Taugher, M. 1996. "Scientists: WIPP Not A Threat," Albuquerque Journal. October 24, 1996. Section A, pages 1,10 .

T139 Hansen, F.D., M.K. Knowles, T.W. Thompson, M. Gross, J.D. McLennan, and J.F. Schatz. 1997. Description and Evaluation of a Mechanistically Based Conceptual Model for Spall. SAND97-1369. Albuquerque, NM: Sandia National Laboratories.

T140 Anonymous. 1997. "Independent Experts: WIPP Conceptual Models Adequate," Carlsbad Current-Argus. May 11, 1997. Section A, page 3.

T141 Corbet, T. 1997. "Expedited CCA Activity: Geochemistry/Hydrology Issue in Culebra." Unpublished Report. Albuquerque, NM: Sandia National Laboratories. (Copy on file in the SWCF as WPO\#43215.)

T142 Taugher, M., and S. Smallwood. 1999. "WIPP Opening Ushers in New Nuclear Era," Albuquerque Journal. March 27, 1999. Section A, pp. 1, 2.

T143 Brooke, J. 1999. "Deep Desert Grave Awaits First Load of Nuclear Waste," New York Times. March 26, 1999. Section A, pp. 1, 18.

T144 Weart, W.D. 1983. Summary Evaluation of the Waste Isolation Pilot Plant (WIPP) Site Suitability. SAND83-0450. Albuquerque, NM: Sandia National Laboratories.

T145 Langston, J. 1999. "Getting the Waste Out," Idaho Falls Post Register. April 28, 1999, Section A, p. 1.

T146 Taugher, M. 1999. "WIPP Receives Colo. Waste," Albuquerque Journal. June 17, 1999 , Section D, p. 1. 


\section{Distribution \\ SAND98-0072 Revision}

\section{Federal Agencies}

US Department of Energy (4)

Office of Civilian Radioactive Waste Mgmt.

Attn: Deputy Director, RW-2

Director, RW-10

Office of Human Resources \& Admin.

Director, RW-30

Office of Program Mgmt. \& Integ.

Director, RW-40

Office of Waste Accept., Stor., \& Tran.

Forrestal Building

Washington, DC 20585

U. S. Department of Energy (3)

Yucca Mountain Site Characterization Office

Attn: Project Director RW-3

A. Van Luik

P. O. Box 30307

Las Vegas, NV 89036-0307

US Department of Energy

Research \& Waste Management Division

Attn: Director

P.O. Box E

Oak Ridge, TN 37831

US Department of Energy (6)

Carlsbad Area Office

Attn: I. Triay

G. T. Basabilvazo

D. Galbraith

M. McFadden

J. A. Mewhinney

Mailroom

P.O. Box 3090

Carlsbad, NM 88221-3090

US Department of Energy

Office of Environmental Restoration and

Waste Management

Attn: M. Frei, EM-30

Forrestal Building

Washington, DC 20585-0002

US Department of Energy (3)

Office of Environmental Restoration and Waste Management

Attn: J. Juri, EM-34, Trevion II

Washington, DC 20585-0002
US Department of Energy

Office of Environmental Restoration and

Waste Management

Attn: S. Schneider, EM-342, Trevion II

Washington, DC 20585-0002

US Department of Energy (2)

Office of Environment, Safety \& Health

Attn: C. Borgstrom, EH-25

R. Pelletier, EH-231

Washington, DC 20585

US Department of Energy (2)

Idaho Operations Office

Fuel Processing \& Waste Mgmt. Division 785 DOE Place

Idaho Falls, ID 83402

US Environmental Protection Agency (2)

Radiation Protection Programs

Attn: M. Oge

ANR-460

Washington, DC 20460

US Environmental Protection Agency

Office of Radiation and Indoor Air

Region 6

Attn: C. Byrum, GT-ET

1445 Ross Avenue

Dallas, TX 75202

US Nuclear Regulatory Commission

Attn: N. E. Eisenberg

MS T7 F3

Washington, DC 20555-0001

\section{Boards}

Defense Nuclear Facilities Safety Board

Attn: D. Winters

625 Indiana Ave. NW, Suite 700

Washington, DC 20004

Nuclear Waste Technical Review Board (3)

Attn: Chairman

J. L. Cohon

C. Di Bella

2300 Clarendon Blvd. Ste 1300

Arlington, VA 22201-3367 


\section{State Agencies}

Attorney General of New Mexico

P.O. Drawer 1508

Santa Fe, NM 87504-1508

Environmental Evaluation Group (3)

Attn: Library

7007 Wyoming NE

Suite F-2

Albuquerque, NM 87109

NM Environment Department (3)

Secretary of the Environment

1190 St. Francis Drive

Santa Fe, NM 87503-0968

NM Bureau of Mines \& Mineral Resources

Socorro, NM 87801

\section{Laboratories/Corporations}

Battelle Pacific Northwest Laboratories

Battelle Blvd.

Richland, WA 99352

Los Alamos National Laboratory

Attn: B. Erdal, INC-12

P.O. Box 1663

Los Alamos, NM 87544

Tech Reps, Inc. (3)

Attn: J. Chapman (1)

Loretta Robledo (2)

5000 Marble NE, Suite 222

Albuquerque, NM 87110

Westinghouse Electric Corporation (5)

Attn: Library

J. Epstein

J. Lee

R. Kehrman

P.O. Box 2078

Carlsbad, NM 88221

S. Cohen \& Associates

Attn: Bill Thurber

1355 Beverly Road

McLean, VA 22101

J. K. Research Associates

Attn: T. Cotton

2650 Park Tower Drive, Suite 800

Vienna, VA 22180
Future Resources Associates, Inc. Attn: R. J. Budnitz, President 2039 Schattuck Ave. Suite 402 Berkeley, CA 94704

Western Water Consultants (2)

Attn: P. A. Rechard

611 Skyline Road

Laramie, WY 82070-8909

Winston \& Strawn

Attn: F. S. Echols

1400 L Street NW

Washington, DC 20005

ICF Consulting

Attn: C. G. Whipple

2101 Webster Street, Suite 1000

Oakland, CA 94612

PLG Incorporated

Attn: B. J. Garrick

4590 MacArthur Blvd., Suite 400

Newport Beach, CA 92660-2027

\section{National Academy of Sciences WIPP Panel}

Tom Kiess (15)

Staff Study Director

GF456

2101 Constitution Ave.

Washington, DC 20418

\section{Universities}

University of New Mexico

Geology Department

Attn: Library

141 Northrop Hall

Albuquerque, NM 87131

University of Washington

College of Ocean \& Fishery Sciences

Attn: G. R. Heath

583 Henderson Hall, $\mathrm{HN}-15$

Seattle, WA 98195

Vanderbilt University

Attn: Frank L. Parker

Department of Environmental Engineering

P.O. Box 1596B

Nashville, TN 37235 
University of Minnesota

Attn: C. Fairhurst

Department of Civil and Mineral Engineering

500 Pillsbury Dr. SE

Minneapolis, MN 55455-0220

University of Michigan

Nuclear Engineering and Radiological Sciences

Attn: R. C. Ewing

2355 Bonisteel Blvd.

Ann Arbor, MI 48109-2104

University of California

Department of Nuclear Engineering

Attn: T. Pigford

4159 Etcheverry Hall

Berkeley, CA 94720

\section{Libraries}

Thomas Brannigan Library

Attn: D. Dresp

106 W. Hadley St.

Las Cruces, NM 88001

Government Publications Department

Zimmerman Library

University of New Mexico

Albuquerque, NM 87131

New Mexico Junior College

Pannell Library

Attn: R. Hill

Lovington Highway

Hobbs, NM 88240

New Mexico State Library

Attn: N. McCallan

325 Don Gaspar

Santa Fe, NM 87503

New Mexico Tech

Martin Speere Memorial Library

Campus Street

Socorro, NM 87810

WIPP Information Center

ATTN: Y. Acosta

4021 National Parks Highway

Carlsbad, NM 88220

\section{Foreign Addresses}

Atomic Energy of Canada, Ltd.

Whiteshell Laboratories

Attn: B. Goodwin

Pinawa, Manitoba, CANADA R0E 1L0

Francois Chenevier (2)

ANDRA

Parc de la Croix Blanche

1-7 rue Jean Monnet

92298 Chatenay-Malabry Cedex

FRANCE

Claude Sombret

Centre d'Etudes Nucleaires de la Vallee Rhone CEN/VALRHO

S.D.H.A. B.P. 171

30205 Bagnols-Sur-Ceze

FRANCE

Commissariat a L'Energie Atomique

Attn: D. Alexandre

Centre d'Etudes de Cadarache

13108 Saint Paul Lez Durance Cedex

FRANCE

University et Marie Curie

Laboratorie de Geologie Applique

Attn: Ghislain deMarsily

4, Place Jussieu

T. 26- Se etage

7522 Paris Cedex 05

FRANCE

Bundesanstalt fur Geowissenschaften und

Rohstoffe

Attn: M. Langer

Postfach 510153

D-30631 Hannover

GERMANY

Bundesministerium fur Forschung und

Technologie

Postfach 200706

5300 Bonn 2

GERMANY

Gesellschaft fur Anlagen und Reaktorsicherheit (GRS)

Attn: B. Baltes

Schwertnergasse 1

D-50667 Cologne

GERMANY 
Bundesant fur Strahlenschutz (BfS)

Attn: P. Brennecke

Postfach 100149

D-38201 Salzgitter

GERMANY

Shingo Tashiro

Japan Atomic Energy Research Institute

Tokai-Mura, Ibaraki-Ken, 319-1 1

JAPAN

Netherlands Energy Research Foundation ECN

Attn: J. Prij

3 Westerduinweg

P.O. Box 1

1755 ZG Petten

THE NETHERLANDS

Svensk Karnbransleforsorjning $A B$

Attn: F. Karlsson

Project KBS (Karnbranslesakerhet)

Box 5864

S-102 48 Stockholm

SWEDEN

Nationale Genossenschaft fur die Lagerung

Radioaktiver Abfalle (2)

Attn: S. Vomvoris

$$
\text { P. Zuidema }
$$

Hardstrasse 73

CH-5430 Wettingen

SWITZERLAND

AEA Technology

Attn: J. H. Rees

D5W/29 Culham Laboratory

Abington, Oxfordshire OX14 3DB

UNITED KINGDOM

AEA Technology

Attn: W. R. Rodwell

044/A31 Winfrith Technical Centre

Dorchester, Dorset DT2 8DH

UNITED KINGDOM

AEA Technology

Attn: J. E. Tinson

B4244 Harwell Laboratory

Didcot, Oxfordshire OX11 ORA

UNITED KINGDOM

B. G. J. Thompson

20 Bonser Road

Twickenham

Middlesex, TWI 4RG

UNITED KINGDOM

\section{Internal}

MS

0612

0701

0701

0706

0716

0735

0737

0759

0778

0779

0779

0779

0771

0771

0771

0733

1395

1395

1395

1395

1399

0731

0731

9018

0899

0612
Org.

0111

6100

6100

6113

6805

6115

6831

6821

6851

6849

6849

6848

6800

6800

6800

6832

6821

6821

6821

6810

6860

6850

6832

6811

8940-2

4916

4912
C. J. Mora

L. Shephard

P. B. Davies

D. E. Munson

R. L. Hunter

T.F. Corbet

E. J. Nowak

M. S. Tierney

H. A. Dockery

D. R. Anderson

R. P. Rechard (5)

H. N. Jow

M. Chu

S. Y. Pickering

W. D. Weart

J. T. Holmes

M. Marietta

B. A. Howard

S. Wagner

N. Z. Elkins

R. D. Waters

S. A. Orrell

C. Northrop-Salazar (2)

NWM Library (100)

Central Technical Files

Technical Library (2)

Review and Approval Desk, For DOE/OSTI 